\title{
Recognizing Risks and Optimizing Perioperative Care to Reduce Respiratory Complications in the Pediatric Patient
}

\author{
Chinyere Egbuta and Keira P. Mason *D \\ Harvard Medical School, Boston Children's Hospital, Department of Anesthesiology, Critical Care and Pain \\ Medicine, 300 Longwood Ave., Boston, MA 02115, USA; Chinyere.Egbuta@childrens.harvard.edu \\ * Correspondence: Keira.Mason@childrens.harvard.edu; Tel.: +1-(617)-355-2339
}

Received: 27 May 2020; Accepted: 17 June 2020; Published: 22 June 2020

check for updates

\begin{abstract}
There have been significant advancements in the safe delivery of anesthesia as well as improvements in surgical technique; however, the perioperative period can still be high risk for the pediatric patient. Perioperative respiratory complications (PRCs) are some of the most common critical events that can occur in pediatric surgical patients and they can lead to increased length of hospitalization, worsened patient outcomes, and higher hospital and postoperative costs. It is important to determine the various factors that put pediatric patients at increased risk of PRCs. This will allow for more detailed and accurate informed consent, optimized perioperative management strategy, improved allocation of clinical resources, and, hopefully, better patient experience. There are only a few risk prediction models/scoring tools developed for and validated in the pediatric patient population, but they have been useful in helping identify the key factors associated with a high likelihood of developing PRCs. Some of these factors are patient factors, while others are procedure-related factors. Some of these factors may be modified such that the patient's clinical status is optimized preoperatively to decrease the risk of PRCs occurring perioperatively. Fore knowledge of the factors that are not able to be modified can help guide allocation of perioperative clinical resources such that the negative impact of these non-modifiable factors is buffered. Additional training in pediatric anesthesia or focused expertise in pediatric airway management, vascular access and management of massive hemorrhage should be considered for the perioperative management of the less than 3 age group. Intraoperative ventilation strategy plays a key role in determining respiratory outcomes for both adult and pediatric surgical patients. Key components of lung protective mechanical ventilation strategy such as low tidal volume and moderate PEEP used in the management of acute respiratory distress syndrome (ARDS) in pediatric intensive care units have been adopted in pediatric operating rooms. Adequate post-operative analgesia that balances pain control with appropriate mental status and respiratory drive is important in reducing PRCs.
\end{abstract}

Keywords: perioperative; complication; pediatric; respiratory; risk factors

\section{Introduction}

Despite significant advancements in the safe delivery of anesthesia and improvements in surgical technique, the perioperative period can still be fraught with risks for the pediatric patient. To date, there is no clearly defined definition for perioperative respiratory complication (PRC). For this review, PRC will comprise of any adverse event that affects the respiratory system occurring either in the intraoperative or the postoperative period. PRCs can lead to increased length of hospitalization, worsened patient outcomes, and higher hospital and postoperative costs [1-6].

This paper will present a comprehensive review of the most recent literature on PRCs in pediatric patients. The authors searched PubMed, Medline, and the Boston Children's Hospital medical e-library 
using the following search terms: postoperative/perioperative/post-surgical respiratory complications solely at first, then further specifying pediatric patients. The authors also used supplementary search methods such as assessing the similarly articles section in PubMed search results and the reference lists of selected studies. The authors included both pediatric and adult studies that are most relevant to clinical practice, while highlighting studies that were published after 2000. Although most of the literature on PRC focus on adult patients, understanding this population's perioperative risk factors, presentation and outcome can, in many cases, aid in and be applicable to the pediatric population. Understanding the perioperative risk factors for PRCs can provide an invaluable opportunity to create and deploy targeted interventions to reduce perioperative morbidity and mortality $[7,8]$.

\section{Definition}

There is no standardized definition of PRC in the pediatric literature. This variability in definition makes it challenging to understand the true incidence and outcome of PRCs, as each study determines the frequency of the respiratory events based on a non-standardized definition, often created for the purpose of the study. To delineate the events that can define a PRC, the European Society of Anaesthesiology assembled a joint taskforce to standardize definitions and outcome measures for perioperative medicine. These definitions were entitled European Perioperative Clinical Outcome (EPCO) definitions and were intended to be used for clinical effectiveness research. Standardized definitions were presented for Respiratory infection, Respiratory failure, Pleural effusion, Atelectasis, Pneumothorax, Bronchospasm, Aspiration pneumonitis, and Pneumonia [9]. To date, no such initiative has been done that is specifically related to pediatrics. Consequently, the literature of pediatric perioperative outcomes include random definitions for laryngospasm, bronchospasm, apnea/hypopnea, hypoxemia or oxygen requirement, hypercarbia or hypoventilation, aspiration airway obstruction, cough, or reintubation (see Table 1 for the published definitions of PRCs in the current pediatric anesthesia literature post-2000). 
Table 1. Incidence of perioperative respiratory complications in major pediatric studies since the year 2000.

\begin{tabular}{|c|c|c|c|c|c|c|}
\hline STUDY & YEAR & DESIGN & PRC(s) Described & Sample Size & PRC C Incidence n (\%) & Surgical Specialty \\
\hline $\begin{array}{l}\text { Habre et al. [10]. } \\
\text { (APRICOT a Study) }\end{array}$ & 2017 & $\begin{array}{l}\text { Prospective, } \\
\text { Multi-Center Cohort }\end{array}$ & $\begin{array}{ll}\text { PRCs } & \\
\bullet & \text { Laryngospasm } \\
\bullet & \text { Bronchospasm } \\
\text { - } & \text { Bronchial Aspiration } \\
\text { - } & \text { Stridor }\end{array}$ & 31127 & 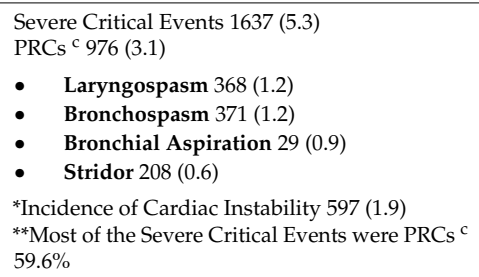 & $\begin{array}{l}\text { Multi-Specialty, Elective } \\
\text { Surgery Only, Ambulatory } \\
\text { Surgery Only }\end{array}$ \\
\hline Schleelein et al. [11] & 2016 & Retrospective, Case-Control & 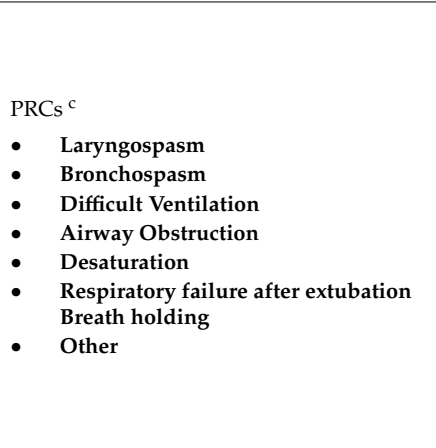 & 55070 & 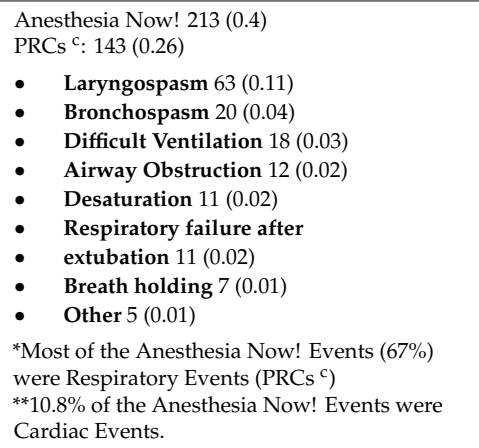 & $\begin{array}{l}\text { Multi-specialty, Elective and } \\
\text { Emergency }\end{array}$ \\
\hline Subramanyam et al. [6] & 2016 & $\begin{array}{l}\text { Prospectively Collected Data, } \\
\text { Retrospective Cohort } \\
\text { Analysis, Single Center }\end{array}$ & $\begin{array}{l}\text { PRCs }{ }^{\mathrm{C}} \\
\text { Intraoperative } \\
\text { - Laryngospasm (Requirement of } \\
\text { PPV > 20cm H2O or Administration } \\
\text { of Succinylcholine) } \\
\text { B Bronchospasm (Use of Albuterol) } \\
\text { Postoperative } \\
\text { - Laryngospasm (Requirement of } \\
\text { PPV > 20cm H2O or Administration } \\
\text { of Succinylcholine) } \\
\text { Bronchospasm (Use of Albuterol) } \\
-\quad \text { Apnea/Hypopnea (Need of Bag } \\
\text { Mask Ventilation) } \\
\text { Oxygen Requirement (Oxygen Need } \\
2 \text { h Post op to Keep Sats > 92\%) }\end{array}$ & 19059 & 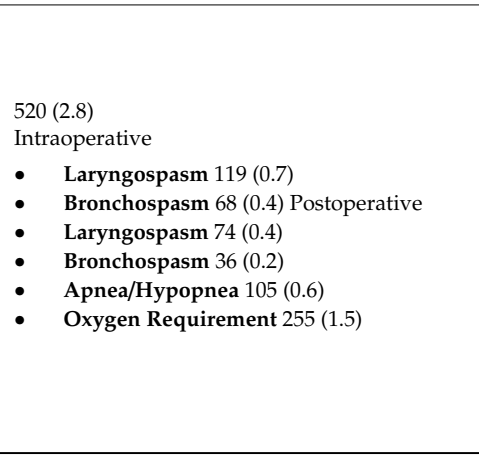 & $\begin{array}{l}\text { Multi-Specialty, } \\
\text { Elective Surgery Only, } \\
\text { Ambulatory Surgery Only }\end{array}$ \\
\hline
\end{tabular}


Table 1. Cont.

\begin{tabular}{|c|c|c|c|c|c|c|}
\hline STUDY & YEAR & DESIGN & PRC(s) Described & Sample Size & PRC $^{\mathrm{C}}$ Incidence n (\%) & Surgical Specialty \\
\hline de Graaff et al. [12] & 2014 & $\begin{array}{l}\text { Retrospective Single- } \\
\text { Center Cohort }\end{array}$ & $\begin{array}{l}\text { 4 out of 20-Item Complication List were } \\
\text { PRCs } c \text { : } \\
\text { - } \\
\text { - } \\
\text { - Brpiration } \\
\text { - Laryngospasm } \\
\text { - Hypoxemia } \\
\text { Hypoventilation } \\
\end{array}$ & 35190 & 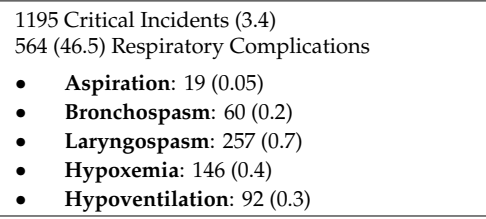 & $\begin{array}{l}\text { Multi-Specialty, Elective, } \\
\text { and Emergency }\end{array}$ \\
\hline $\begin{array}{l}\text { Kurth et al. [13] } \\
\text { (Wake-Up Safe) }\end{array}$ & 2013 & $\begin{array}{l}\text { Prospective, } \\
\text { Multi-Center Cohort }\end{array}$ & Respiratory Events & 736365 & 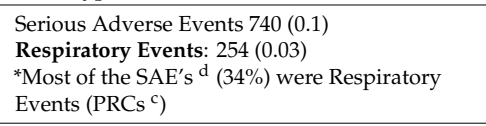 & $\begin{array}{l}\text { Multi-Specialty, } \\
\text { Elective and Emergency }\end{array}$ \\
\hline $\begin{array}{l}\text { Von Ungern- } \\
\text { Sternberg et al. [14] }\end{array}$ & 2010 & $\begin{array}{l}\text { Prospective, } \\
\text { Single-Center Cohort }\end{array}$ & 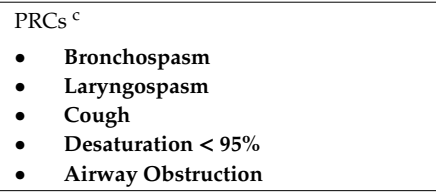 & 9297 & $\begin{array}{ll}1392(15) \\
\bullet \quad & \text { Bronchospasm } 193(2) \\
\bullet & \text { Laryngospasm } 351(4) \\
\bullet & \text { Cough } 687(7) \\
& \text { Desaturation }<95 \% 919(10) \\
- & \text { Airway Obstruction } 332(4) \\
\end{array}$ & $\begin{array}{l}\text { Otolaryngology, } \\
\text { Elective and Emergency }\end{array}$ \\
\hline $\begin{array}{l}\text { Bhananker et al. [15] } \\
\text { (POCA }{ }^{\text {b Study) }}\end{array}$ & 2007 & $\begin{array}{l}\text { Prospective, } \\
\text { Multi-Center Cohort }\end{array}$ & 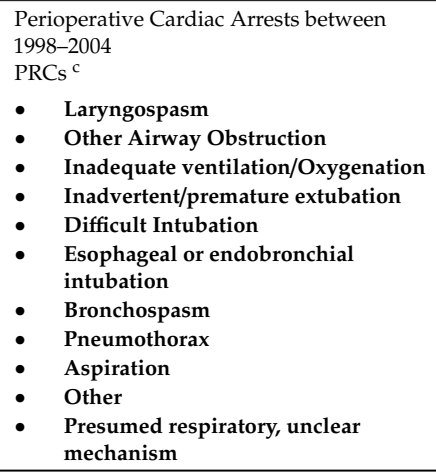 & 193 & 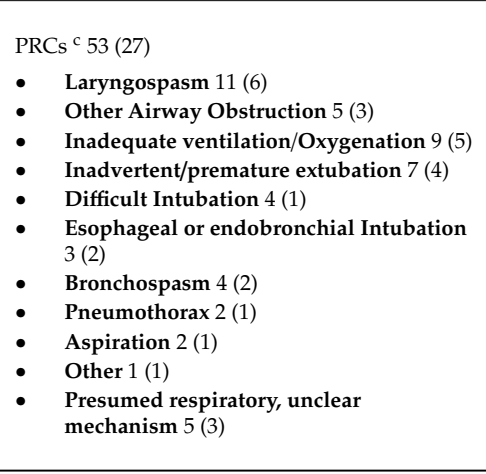 & $\begin{array}{l}\text { Multi-specialty, } \\
\text { Elective and Emergency }\end{array}$ \\
\hline
\end{tabular}


Table 1. Cont

\begin{tabular}{|c|c|c|c|c|c|c|}
\hline STUDY & YEAR & DESIGN & PRC(s) Described & Sample Size & PRC $^{\mathrm{C}}$ Incidence n (\%) & Surgical Specialty \\
\hline Mamie et al. [16] & 2004 & $\begin{array}{l}\text { Prospective, } \\
\text { single Center Cohort }\end{array}$ & $\begin{array}{l}\text { PRCs }{ }^{\mathrm{C}} \\
\text { - Laryngospasm (Complete Airway } \\
\text { Obstruction Associated with Muscle } \\
\text { Rigidity of Abdominal Wall or Chest } \\
\text { Wall, Unrelieved by Maneuvers to } \\
\text { Relieve Soft Tissue Obstruction) } \\
\text { - Bronchospasm (Increase in } \\
\text { Respiratory Effort, Especially } \\
\text { Expiration, Associated with } \\
\text { Hypercapnia and Oxygen } \\
\text { Desaturation, Wheeze on Auscultation, } \\
\text { Capnography Changes in Ventilated } \\
\text { Patients with Increase in the Slope of } \\
\text { the Plateau, and Increase in Airway } \\
\text { Peak Pressure) } \\
\text { - Airway Obstruction (Partial Airway } \\
\text { Obstruction with Snoring Noise and } \\
\text { Respiratory Efforts Without Deep } \\
\text { Desaturation; Relieved Easily by Jaw } \\
\text { Thrust, Positive Airway Pressure } \\
\text { and/or a Guedel Airway) } \\
\text { Oxygen Desaturation (SpO2 }<95 \% \text { ) } \\
\text { - Recurrent Cough }\end{array}$ & 757 & 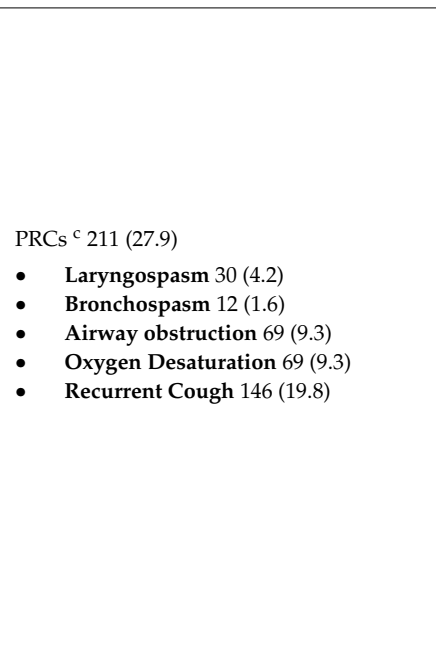 & $\begin{array}{l}\text { Multi-Specialty, } \\
\text { Elective Surgery Only }\end{array}$ \\
\hline Murat et al. [17] & 2004 & $\begin{array}{l}\text { Prospective, } \\
\text { Single Center Cohort }\end{array}$ & $\begin{array}{ll}\text { PRCs } & \\
\text { - } & \text { Bronchospasm } \\
\text { - } & \text { Hypercarbia } \\
\text { - } & \text { Hypoxemia } \\
\text { - } & \text { Aspiration } \\
\text { - } & \text { Laryngospasm } \\
\text { - } & \text { Reintubation }\end{array}$ & 23043 & 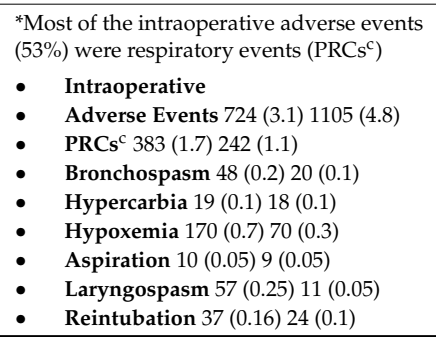 & $\begin{array}{l}\text { Multi-specialty, Elective and } \\
\text { Emergency surgery }\end{array}$ \\
\hline
\end{tabular}


Table 1. Cont.

\begin{tabular}{|c|c|c|c|c|c|c|}
\hline STUDY & YEAR & DESIGN & PRC(s) Described & Sample Size & PRC C Incidence n (\%) & Surgical Specialty \\
\hline Budic et al. [18] & 2004 & $\begin{array}{l}\text { Prospective, } \\
\text { Single Center Cohort }\end{array}$ & $\begin{array}{l}\text { *Adverse Respiratory Events were Defined } \\
\text { as any Eisode of Perioperative Airway } \\
\text { Obstruction (e.g., Laryngospasm), Oxygen } \\
\text { Desaturation Less than } 90 \% \text { (for } \geq 10 \mathrm{~s} \text { ), } \\
\text { Breath Holding ( } \geq 15 \mathrm{~s}), \text { Severe Coughing, } \\
\text { and Any Requirement for Unanticipated } \\
\text { Endotracheal Intubation. } \\
\text { PRCs }{ }^{c} \\
\text { - Laryngeal Spasm } \\
\text { (Complete Obstruction) } \\
\text { - Laryngeal Inspiratory Stridor } \\
\text { (Partial) } \\
\text { Irregular Breathing (Breath Holding) } \\
\text { - Apnea } \\
\text { - Cough } \\
\text { - } \quad \text { Exccup } \\
\text { - Obsstruction by Tongue }\end{array}$ & 682 & $\begin{array}{ll}\text { PRCS } & \mathrm{c} 39(5.71) \\
\text { - } & \text { Laryngeal Spasm } 3(0.44) \\
\text { - } & \text { Laryngeal Inspiratory Stridor } 15(2.2) \\
\text { - } & \text { Irregular Breathing } 10(1.47) \\
\text { - } & \text { Apnea } 3(0.44) \\
\text { - } & \text { Cough } 3(0.44) \\
\text { - } & \text { Hiccup } 3(0.44) \\
\text { - } & \text { Excess Secretions } 1(0.14) \\
\text { Obstruction by Tongue } 1(0.14)\end{array}$ & $\begin{array}{l}\text { Multi-Specialty, Elective and } \\
\text { Emergency Surgery }\end{array}$ \\
\hline Tay et al. [19] & 2001 & $\begin{array}{l}\text { Prospective, } \\
\text { Single Center Cohort }\end{array}$ & 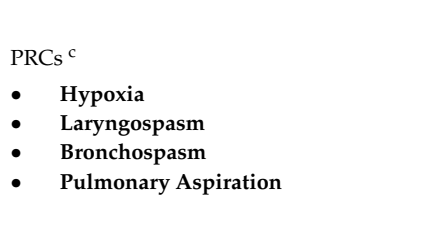 & 10000 & $\begin{array}{l}297 \text { Damaging Events Described } \\
{ }^{*} \text { Most of the Damaging Events }(77 \%) \text { were } \\
\left.\text { Respiratory Events (PRCs }{ }^{\circ}\right) \\
\text { PRCs } 230(77.44) \\
\text { - } \quad \text { Hypoxia } 101(34) \\
\text { - Laryngospasm } 106(35.7) \\
\text { - } \quad \text { Bronchospasm } 20(6.7) \\
\text { - }\end{array}$ & $\begin{array}{l}\text { Multi-Specialty, Elective and } \\
\text { Emergency Surgery }\end{array}$ \\
\hline
\end{tabular}

a APRICOT, Anaesthesia Practice in Children Observational Trial; ${ }^{\mathrm{b}}$ POCA, pediatric perioperative cardiac arrest; ${ }^{\mathrm{c}}$ PRC, perioperative respiratory complication; ${ }^{\mathrm{d}}$ SAE, serious adverse event. Bold font denotes a PRC. 


\section{Incidence}

PRCs are some of the most common critical events that can occur in pediatric surgical patients [6,9-19]. It has been estimated that of all the perioperative damaging events (297 damaging events per 10,000 anesthetics), over $75 \%$ involve the respiratory system, of which $36 \%$ are related to laryngospasm [19]. In 2013, the Wake-Up Safe (WUS) initiative concurred: Respiratory etiology for Serious Adverse Events (SAE) represented 34\% of the overall 1.4 per 1000 pediatric anaesthetics [13]. Table 1 summarizes the varied incidence of PRCs, which has been reported in the literature $(0.1$ to $3 \%$ of anesthetics) since 2000.

\section{Cost, Morbidity and Mortality}

The Agency for Healthcare Research and Quality (AHRQ) developed Patient Safety Indicators (PSI), reviewing in-hospital data up to time of discharge, in order to identify potential pediatric inpatient safety issues [2]. They reported postoperative respiratory failure in 33 per 1000 pediatric patients ( 0 to 18 years) [2]. The financial burden of these events were significant: An average of 24.4 additional days in the hospital, $\$ 140,507$ in increased charges and an increased risk of in-hospital mortality (Odds Ratio 76.6) [2]. A similar study was conducted, examining outcome data after hospitalization at 38 freestanding pediatric, academic, not-for-profit, tertiary care hospitals. In these settings, postoperative respiratory failure was a leading cause of hospital expenses: an average of 4.8 extra days in-hospital and excess total charges of $\$ 77,739$ on average [1].

Malpractice closed claims offer important insights into the types of events that lead to morbidity and mortality. There is a significantly higher rate of closed claims related to PRCs for pediatrics than adults with substantial morbidity, mortality and successful monetary awards [6]. In a review of $69 \mathrm{New}$ York State insurance claims and 87 national court trials alleging injury related to tonsillectomy, of which there were 38 deaths/major injury with 36 cases presenting an identifiable etiology, PRCs represented 13 out of the 36 identifiable causes of death/major injury [20].

\section{Preoperative Risk Assessment and Stratification}

The anatomy of a child's airway evolves quite dramatically from birth to adolescence. The proximity of pharyngeal structures combined with smaller mandibles, smaller tracheal diameter as well as relatively large tongues lead to significantly increased risk of airway obstruction in infants and young children. It is important to identify the various factors that predict an increased risk of pediatric PRCs. This identification will improve our ability to advise patients for informed consent, optimize perioperative management strategy, improve allocation of clinical resources, and, identify PRCs for quality metrics and research purposes. Although there are published studies describing risk factors for PRCs, there remains a paucity of validated predictors and models for pediatrics. In the following section, the preoperative and perioperative risk factors which have been examined as posing an increased risk for PRCs will be evaluated.

\subsection{Pediatric Preoperative Risk Prediction Tools}

\subsubsection{Snoring, Trouble Breathing, and Un-Refreshed (STBUR) Questionnaire}

The STBUR Scale is a 5-item questionnaire that has been developed from the Sleep-Related Breathing Disorder (SRBD) questionnaire, which has been validated in children with sleep disordered breathing (SDB) [21]. A prospective study of 337 parents compared responses on the SRBD questionnaire with the occurrence of Perioperative Respiratory Adverse Events (PRAE) which included major cough, major breath-hold, laryngospasm, bronchospasm, airway obstruction, major desaturation and critical PRAE [21]. The STBUR tool was created by identifying the five symptoms from the SRBD questionnaire which were strongly predictive of the occurrence of PRAE. The positive likelihood ratio of PRAE was 3.06 (three-fold higher) in the presence of any 3 STBUR symptoms, 9.74 (ten-fold higher) with 5 STBUR symptoms, and 2.6 when using only polysomnography (PSG)-confirmed diagnosis of SDB [21]. 
The STBUR Questionnaire could replace the SRBD and PSG by offering a more accurate method to predict children at risk for SDB and PRAE [6,21].

5.1.2. Perioperative Respiratory Adverse Events in Pediatric Ambulatory Anesthesia: Risk Prediction Tool

A large study of 19,059 children (age < 18 years) were divided into two cohorts: Derivation Cohort and Validation Cohort [6]. The derivation cohort was used to develop a risk prediction tool from the $3.9 \%$ of patients who suffered a perioperative respiratory event of laryngospasm, bronchospasm (intra or postoperative) or postoperative apnea, hypopnea or prolonged oxygen requirement [6].

Age ( $\leq 3$ years), ASA $>1$, morbid obesity, preexisting pulmonary disorder, and anesthesia for surgery (versus radiology) were predictors of increased risk [6]. The Validation Cohort was then used to demonstrate the predictive validity of the tool. The discriminant performance of the final risk tool was most valuable in predicting those who would not have a high risk of a perioperative event. The tool had a negative predictive value of 98.2 , positive predictive value of 5.8 , sensitivity of 77.6 and specificity of 49.2 [6].

\subsubsection{The COLDS Score}

The COLDS Score is a preoperative screening tool that has been validated in children $<6$ years of age and intended to quantify the risk of PRCs. COLDS is an acronym for the identified risk factors for PRCs: C for current signs and symptoms; O for onset of symptoms; L for lung disease; $\mathrm{D}$ for the device to be used for airway management; and $S$ for surgery type (whether it involves the airway or not, then further subclassified to major and minor airway) [22]. The COLDS score assigns each risk factor a numerical score of 1,2 or 5 to quantify the risk as nil, mild or moderate/severe, respectively. A higher COLDS score would suggest more perioperative risk. The COLDs score has a high interrater reliability, most predictive in neonates and infants (age 0 to $<2$ years) [22].

The COLDS score is most valuable in predicting bronchospasm, desaturation, the need for beta-agonist therapy and prolonged cough and less able to predict the occurrence of laryngospasm. The COLDS Score has been shown to be predictive of the cancellation of a planned surgical procedure for anesthesia-related concerns. In one study, all patients who had a COLD score of 19 and above were almost always cancelled [22].

\subsection{Risk Factors for Perioperative Respiratory Complications}

Table 2 summarizes the risk factors that have been identified with pediatric perioperative respiratory complications since 2000. The table has been structured to be used as a preoperative tool not only to identify risk factors (patient and procedure) but also possible modifications (modifiable and non-modifiable) to patient care which could be made to optimize outcome and minimize risk. 
Table 2. Published risk factors for developing perioperative respiratory complications in pediatric patients categorized into patient factors and procedure factors which are both sub-categorized into non-modifiable and modifiable.

\begin{tabular}{|c|c|}
\hline PATIENT FACTORS & PROCEDURE FACTORS \\
\hline Modifiable & Modifiable \\
\hline 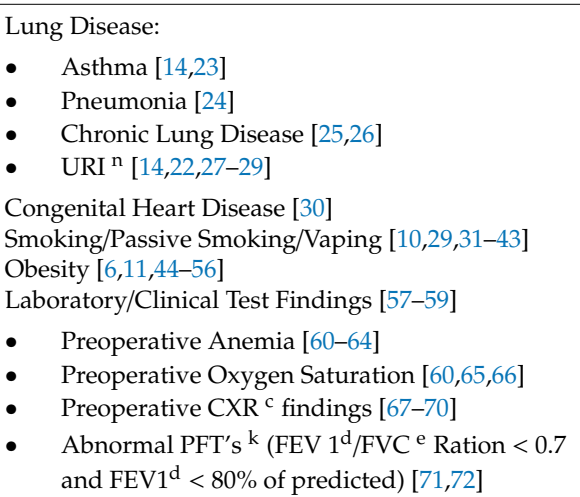 & $\begin{array}{l}\text { Pediatric Anesthesiologist versus General }[10,16,19,73-75] \\
\text { GA }{ }^{\mathrm{f}} \text { Versus Regional }[10,14,60,76,77] \\
\text { Duration of Procedure (Long versus Short) }[10,11,78-80] \\
\text { Re-Operation [11] } \\
\text { Complexity of Procedure (Simple versus Complex) [11] } \\
\text { Location (OR }{ }^{\mathrm{i}} \text { versus Remote Location) [6,11] } \\
\text { Long-Acting NMBDs }{ }^{\mathrm{h}} \text { [7,81] } \\
\text { Sugammadex [81-87] } \\
\text { Supraglottic Airway Versus Endotracheal Airway [14,18,88] } \\
\text { Open Versus Laparoscopic Abdominal Surgery [89-92] } \\
\text { Intraoperative Blood Product Transfusion }[76,93-96] \\
\text { Mechanical Ventilation Strategy }[7,24,25,97-129]\end{array}$ \\
\hline Non-Modifiable & Non-Modifiable \\
\hline 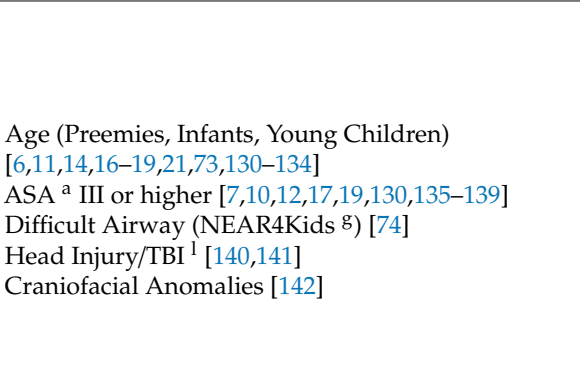 & $\begin{array}{ll}\text { Type of Surgery } \\
\text { - } & \text { OSA } \mathrm{j} / \text { Adenotonsillectomy }[14,16,17] \\
\text { - } & \text { Head and Neck }[14,16,17] \\
\text { - } & \text { Pyloric Stenosis }[64] \\
\text { - } & \operatorname{TEF}^{\mathrm{m}}[143,144] \\
\text { - } & \mathrm{CDH}^{\mathrm{b}}[145] \\
\text { - } & \text { Gastroschisis }[146,147] \\
\text { - } & \text { Omphalocele }[146,147] \\
\text { - } & \text { Peurosurgery }[148,149] \\
\text { - } & \text { Elective versus Emergency }[7,12,18,135]\end{array}$ \\
\hline
\end{tabular}

\footnotetext{
a ASA, American Society of Anesthesiologists; ${ }^{\mathrm{b}} \mathrm{CDH}$, congenital diaphragmatic hernia; ${ }^{\mathrm{c}} \mathrm{CXR}$, chest x-ray; ${ }^{d}$ FEV1, forced expiratory volume in 1 second; ${ }^{e}$ FVC, forced vital capacity; ${ }^{f}$ GA, general anesthesia; ${ }^{g}$ NEAR4kids, National Emergency Airway Registry for Children; ${ }^{\mathrm{h}} \mathrm{NMBDs}$, neuromuscular blocking drugs; ${ }^{\mathrm{I}} \mathrm{OR}$, operating room; $j$ OSA, obstructive sleep apnea ; $k$ PFTs, pulmonary function tests; ${ }^{l}$ TBI, traumatic brain injury; ${ }^{\mathrm{m}}$ TEF, tracheoesophageal fistula; ${ }^{\mathrm{n}}$ URI, upper respiratory illness.
}

\subsubsection{Non-Modifiable Risk Factors}

Age

Multiple pediatric studies have shown that the risk of PRCs decreases as the child ages $[6,11,14,16,17,19]$. Figure 1 shows the distribution of severe critical (respiratory and cardiovascular) events across pediatric age groups ( $0-16$ years) in a prospective multicenter observational study in 261 hospitals in Europe [10]. Infants, particularly neonates, have the greatest risk of critical events intraoperatively and they tend to suffer primarily from PRCs [11,12,16,18,21,73,130,131]. Young and premature infants are at an even higher risk of PRCs as compared to full-term and older premature infants [130]. Studies have recommended that infants be at least 44 weeks post conceptual age for non-essential surgeries to decrease their risk of PRCs $[132,133]$. Kurth et al. expressed concern that preterm infants less than 60 weeks post-conceptual age were also at increased risk of PRCs [134]. These findings are in opposition with adult studies which, even after adjusting for co-morbidity, identify advancing age (age $>60$ to 65 years) as a risk factor [7]. 


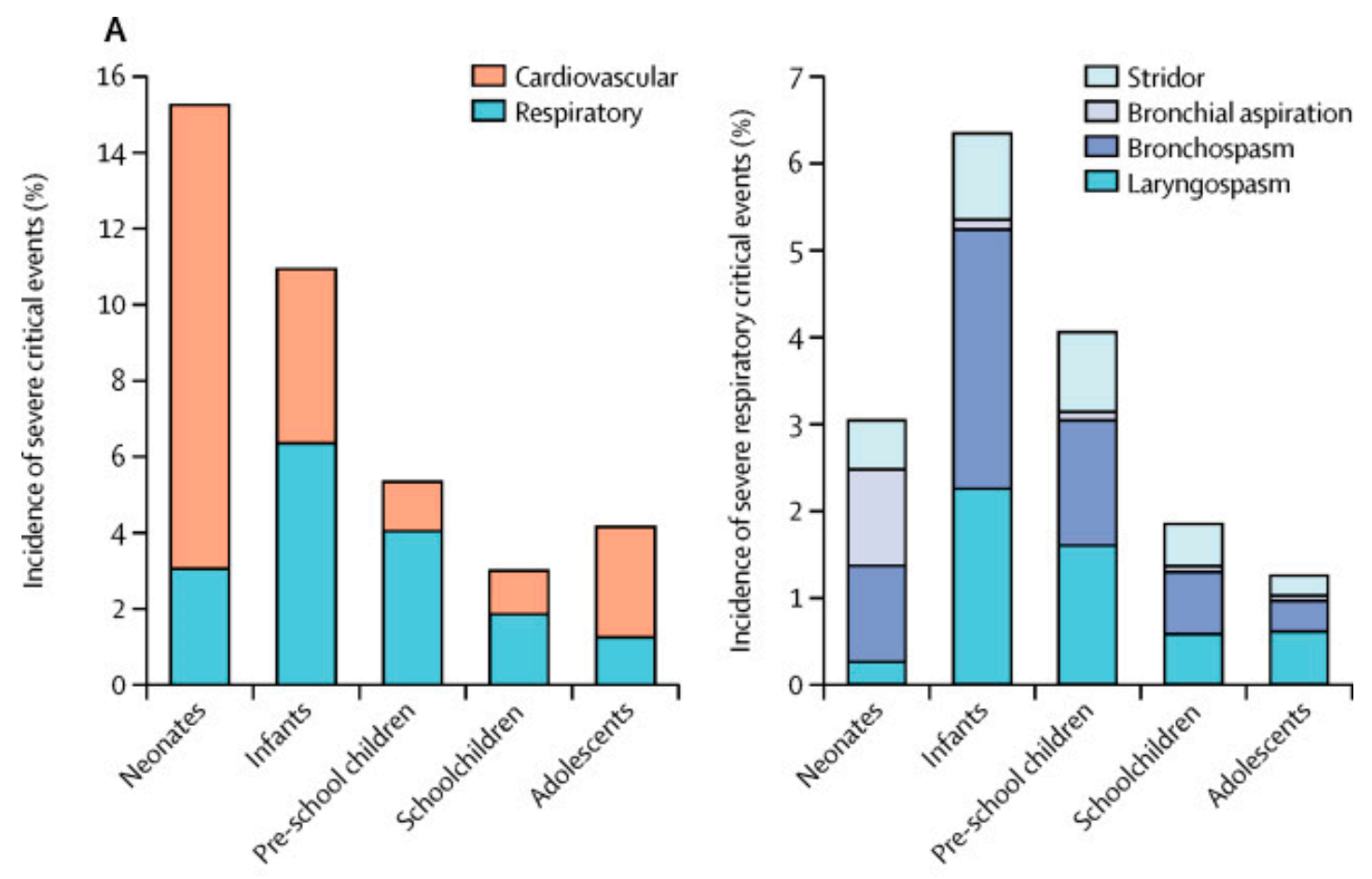

B

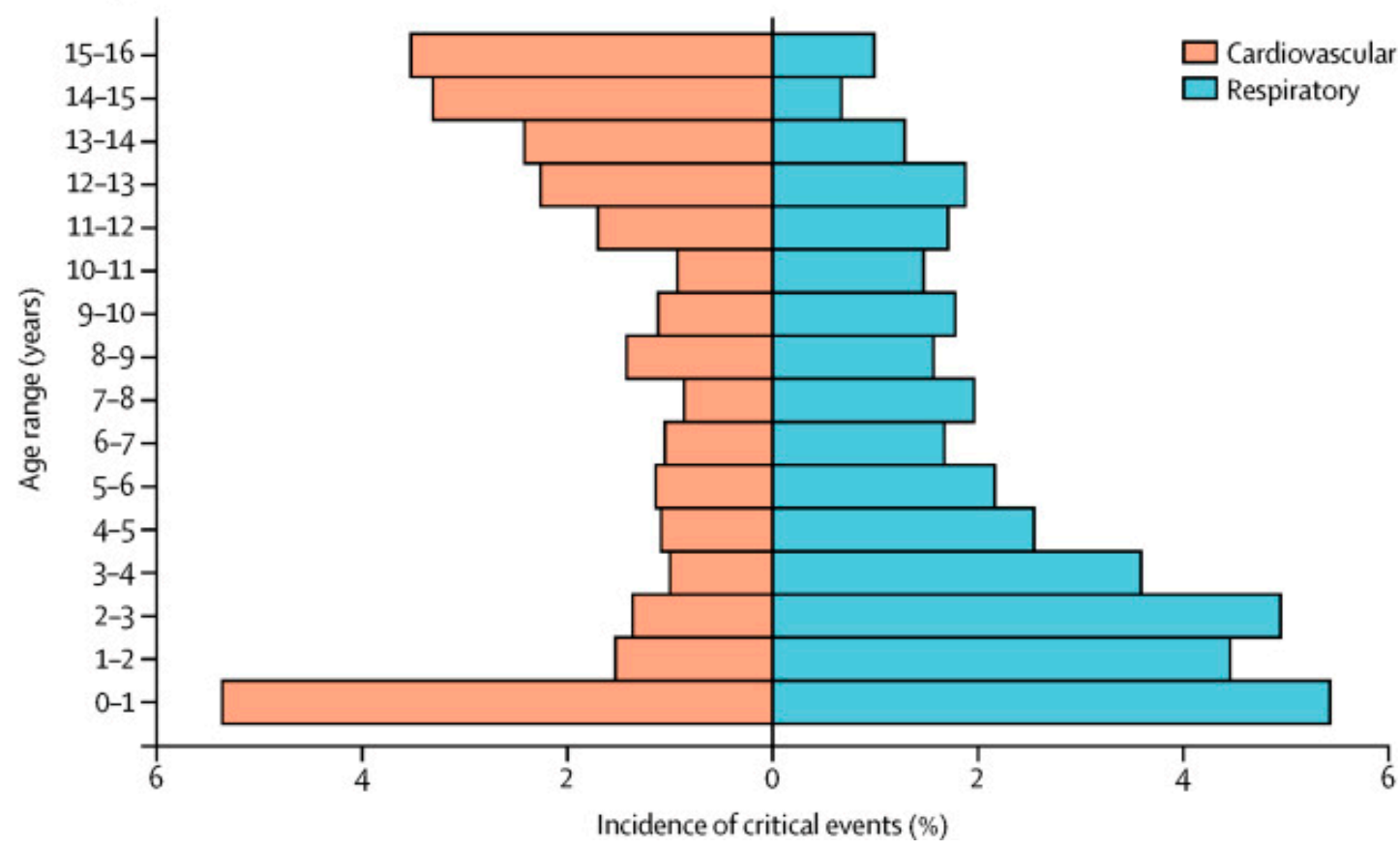

Figure 1. Distribution of severe critical events throughout the age groups. (A) Relative incidence and of respiratory and cardiovascular events (\%) and the relative distribution of the four respiratory critical events (\%). (B) Age distribution of cardiovascular (orange) and respiratory (blue) critical events [10].

ASA Status

An American Society of Anesthesiologists Physical Status $\geq 3$ increases the risk of PRCs by 4-14 fold in children $[7,10,12,17,19,130,135]$.

Although the interrater reliability has not been as predictive as in the adult population, the ASA's modification in 2014 of the ASA classification with approved clinical scenarios tailored to each definition, could improve the interrate reliability [136-138]. 
Despite the limitations of the ASA-PS classification system, an ASA score $\geq 3$, alone or in combination with other clinical variables (co-morbidities, type of surgery, etc.) can guide the perioperative anesthetic care of the pediatric patient $[6,10]$.

Although the overall incidence of medical malpractice claims in pediatrics is less than adults, the morbidity and mortality tend to be more significant: ASA 3-5 patients comprises only $23 \%$ of pediatric anesthesia closed malpractice claims. A total of $33 \%$ of these claims, however, resulted in death or brain damage, most commonly from respiratory and cardiovascular events $[73,139]$.

Type of Surgery

Pediatric patients have been shown to be at greater risk of developing PRCs after otolaryngology (ENT) surgical procedures [14,16,17]. One study cites a 1.6 fold increase risk of PRCs after ENT surgery, with an odds ratio of 1.43 versus 2.74 for non-ENT and ENT procedures, respectively [16]. A total of two or more surgical procedures from different specialties has also been shown to increase the risk of critical events (the majority representing respiratory) in children by over 2-fold [11]. Pediatric procedures performed outside of the operating room (OOR) setting have been shown to pose up to a 2.71 increase risk, with a critical event rate of 1:814 versus 1:213 in OOR and operating room settings, respectively $[6,11]$. Further studies are required to determine whether patient demographics (ASA score, medical risk factors, age) or the setting (proximity to emergency aid, ancillary back-up services, equipment availability, familiarity of anesthesia staff with the OOR environment etc.) play a role in this significant discrepancy in risk.

Adult studies report differently, with abdominal and vascular surgeries representing higher risk for PRCs [7].

Both adult and pediatric literature report an increased risk of PRCs in emergent procedures. Although the degree of increased risk has not been estimated in children, the adult literature report a two- to six-fold increase in PRC risk as compared to elective procedures $[7,12,18,135]$.

Preoperative Studies

Preoperative Labs, Chest X ray, Pulmonary Function Tests, Oxygen Saturation and Arterial Blood Gas

Preoperative evaluation of the pediatric patient should ultimately focus on minimizing the risk of PRCs by identifying any potential risk factors. Particularly, as we know that respiratory events (both upper and lower) account for a majority of pediatric PRCs, it is important to perform a thorough pulmonary and airway exam and review of systems. A routine preoperative laboratory assessment should be reserved for those whose medical or family history, review of systems or impending procedure, warrants focused preoperative testing [57-59].

There is no demonstrated value in obtaining routine chest $\mathrm{X}$-rays in otherwise healthy pediatric patients who do not have baseline or acute lung disease, are not scheduled for major thoracic or abdominal surgery, do not smoke, are not on immunosuppressive therapy and do not have any risk factors for tuberculosis [67-70].

Similarly, pre-operative pulmonary function tests (PFTs) for those children who are scheduled for scoliosis and posterior spinal fusions, procedures with a presumptive high risk of perioperative complications and post-operative ventilation, have not been shown to be of value. A total of $30 \%$ of all children scheduled for these procedures were unable to deliver effective PFTs, and of the approximately $10 \%$ (37 of 357) who were found to be at high risk, only one remained intubated post-operatively. PFTs have not to-date been shown to be effective as a predictor for PRCs, post-operative intensive care unit admission or need for post-operative ventilation [71]. Similarly, spirometry has not been shown to be an effective predictor: a systematic review of blinded studies reported that $80 \%$ of spirometry values did not predict PRCs [72].

The role of preoperative oxygen saturation and arterial blood gas (ABG) tests has yet to be determined for the pediatric patient. Both have been shown to be helpful in predicting the risk of 
developing PRCs in adults $[60,65,66]$. Future studies are required to determine whether there is a predictive value for pre-operative oxygen saturations in children and, the possible role of ABG testing balanced with the logistical challenges which would be involved in obtaining them.

\section{The Pediatric Difficult Airway}

Difficult intubation, whether anticipated or unanticipated, has been shown to increase the risk of PRCs and perioperative cardiac arrest $[10,15,74]$. The Pediatric Difficult Intubation Registry (PeDI) reports that $20 \%$ of children with difficult tracheal intubations suffered at least one complication. PRCs comprised most non-severe complications and included transient hypoxemia (the most common), minor airway trauma, laryngospasm, and bronchospasm. Cardiac arrest occurred in $2 \%$ of the patients [74].

The PeDI registry was evaluated to find predictors of difficult intubations which was defined as requiring more than two attempts at direct laryngoscopy (DL): weight $<10 \mathrm{~kg}$, short thyromental distance, and three direct laryngoscopy (DL) attempts prior to deploying indirect technique. A difficult intubation was associated with high rates of failed intubation and up to a $30 \%$ incidence of severe complications. Strategies to minimize the risk of hypoxia and repeated intubations included pre-oxygenation via facemask and passive oxygen administration (nasal cannula) during active instrumentation of the airway. Early recognition of a difficult airway with rapid transition from direct to indirect laryngoscopy has been shown to be effective in a difficult airway situation [74].

\subsubsection{Modifiable Risk Factors}

It is important to carefully evaluate the patient as well as the procedure to determine whether there are any opportunities to minimize the risk of PRCs either pre- or intra-operatively.

\section{Patient Factors}

Co-morbidity

Children with significant comorbidities and an ASA classification $\geq 3$ have a higher likelihood of critical events in the perioperative period $[6,10,151]$. The American College of Surgeons introduced a National Surgical Quality Improvement Program (ACS NSQIP) as an initiative to minimize the surgical risks for children. They reported that comorbidities of nutritional/immune history (preoperative weight loss or chronic steroid use), physiologic compromise (sepsis, inotrope use prior to surgery) and ASA $>3$ were associated with a higher likelihood of postoperative complications [151].

Preexisting pulmonary (odds ratio 3.95) and neurologic disease (OR 1.41) were also associated with increased PRC risk [6]. Sleep disordered breathing (SDB) has been noted to be associated with up to a two fold increase in PRC $[10,22,152]$. Airway insensitivity (history of wheezing, asthma diagnosis) has been reported to pose up to a threefold increased risk [10].

Congenital heart disease (CHD), even when undergoing non-cardiac surgery, is a risk factor for both cardiovascular $(11.5 \%)$ and respiratory $(4.7 \%)$ PRC in children. Non-cardiac surgery included otolaryngology, maxillofacial, gastroenterology and general surgical procedures. The more severe the CHD, the higher the risks of reintubation and mortality [30].

Children with asthma should be optimized from a respiratory standpoint prior to surgery. All asthma medications should be continued up to and including day of surgery and corticosteroids (inhaled or systemic) and short-acting inhaled beta agonists pre-operatively [153-155].

Obstructive sleep apnea poses an inherent risk for PRCs in children. A detailed assessment of diagnostic sleep studies, home monitors (pulse oximeter, apnea monitor) as well as non-surgical home medical management (supplemental oxygen, bi-level positive airway pressure [BiPAP], continuous positive airway pressure [CPAP], preferred sleep position) should be obtained [156]. These details will aid in the planning of pre, peri and postoperative management. Home CPAP and BiPAP machines should accompany the child on day of surgery, and in some cases, may be used in the post-operative and recovery period as well as in the transport home after discharge [156]. 
Upper Respiratory Infection (URI)

There is a significantly increased risk of PRCs in children with acute or recent $(<2$ weeks) upper respiratory infection (URI) [14,22,27-29]. The precise time of risk following a URI remains unclear: Some studies suggest that airway inflammation and hypersensitivity can last up to several weeks, while others advocate that the risk is for only the first two weeks after the beginning of URI symptoms. Tait et al. found a higher risk of PRCs in patients with active or recent URI to last up to 4 weeks after URI symptoms resolve; however, none of the PRCs led to any long-term adverse sequelae [29]. The consensus of most pediatric anesthesiologists is that elective surgery be delayed until 2-3 weeks following resolution of URI symptoms $[27,28]$.

In the event that an anesthetic is necessary for a child with an active URI, there are increased risks of PRC with endotracheal intubation, age $<5$ years, history of prematurity, history of reactive airway disease, parental smoking, surgery involving the airway, presence of copious secretions, and nasal congestion. An endotracheal intubation increased the likelihood of breathholding, severe cough, and desaturation $<90 \%$. When comparing ETT to LMA in these URI patients, the ETT was associated with a higher rate of significant desaturation but had similar rates of cough and breathholding as LMA [29].

\section{Obesity}

Up to one-third of pediatric surgical patients suffer from obesity [11,44-46]. Childhood obesity is linked to many other major comorbidities, similar to adults, like: hypertension, type II diabetes, heart disease, hyperlipidemia, and asthma [47-50]. Obesity increases the likelihood of apnea/hypopnea, a difficult mask airway, laryngospasm (the most common PRC in children), severe desaturation, cardiac arrest and an increased postoperative oxygen requirement [6,52-55]. Sleep disordered breathing is more common with pediatric obesity ranging from snoring to obstructive sleep apnea (OSA) [51]. The APRICOT study, a prospective observational multicenter European cohort identified the incidence, nature, and outcome of severe critical events in children in the perioperative period. Snoring increased the risk of severe critical events (most of which were PRCs) by two-fold [10].

In adults, weight loss of $5 \%-10 \%$ has been shown to significantly reduce the perioperative risk of complications from chronic comorbidities often associated with obesity. Although no such study has been done in children, consideration should be given to weight reduction pre-operatively, especially in morbidly obese children presenting for procedures who also have existing risk factors predisposing them to PRC [56].

Smoking/Passive SMOKING/vaping

Passive smoking (exposure to cigarette smoke) is associated with increased risk (relative risk RR 1.39) of PRCs $[10,29]$. Children of smokers have a higher incidence of breathing problems, airway reactivity, asthma exacerbation and PRCs, particularly in children with active URI (RR 1.6) [29,31-35].

In adults, a meta-analysis comparing current smokers and ex-smokers of at least 4 weeks or greater showed a significant reduction in PRCs for ex-smokers (RR 0.81) [36]. Smoking cessation for $>4$ weeks and $>8$ weeks pre operatively can decrease the incidence of PRCs by $23 \%$ and by $47 \%$, respectively [36,37]. An active smoking intervention program demonstrates a higher cessation rate (up to $25 \%$ ) compared to those without active engagement (8\%) [38]. With these adult studies in mind, active counseling and intervention should be attempted in adolescents and children who smoke, as well as of their parents who are exposing them to passive smoke [39].

Electronic cigarettes (e-cigarettes)/vaping devices (both nicotine and, less commonly, non-nicotine) have not been shown to have benefits in either short- or long-term cessation [40]. The prevalence of vaping amongst adolescents in 8th, 10th, and 12th grade has more than doubled between 2017 and 2019 ( 3.5 to $9,8.2$ to 20.2, and 11.0 to 25.4, respectively) [41]. This is particularly concerning given the potential link recently described between vaping and acute lung injury [42]. Airway burns created by the inhaled chemical agents can lead to a constellation of pathophysiologic signs similar to Acute Respiratory Distress Syndrome (ARDS): inflammation, airway edema with sloughing of the epithelium, 
alveolar inflammation, and hypoxemia [43]. Preoperative screening for vaping/e-cigarette use and its potentially associated symptoms amongst early teens/adolescents is warranted.

Preoperative Anemia and Blood Transfusion

Anemia is reported in up to $17 \%$ of children presenting for routine preoperative screening for elective surgery [61]. Although a higher incidence of in-hospital mortality has been reported in anemic neonates and children presenting for non-cardiac surgery, it is important to consider this in the context which was extremely ill children for complex surgical procedures $[62,63]$. Preoperative anemia, defined as hematocrit $<40 \%$ for neonates and $<30 \%$ for infants $>30$ days old as well as toddlers to adolescents, in otherwise healthy children $<1$ year of age has not been associated with PRCs in the setting of uncomplicated surgeries [64].

The value of preoperative transfusions in the setting of anemia remains unclear. In adults, this practice has not been shown to decrease the risk of developing PRCs in this at-risk population. Rather, transfusions have increased the risk of PRC $[60,76,93,94]$. A systematic review with metaanalyses of randomized controlled trials comparing a restrictive versus liberal transfusion strategy in both adult and pediatric patients reported no differences in mortality or morbidity between the two strategies, despite reduced number of packed red blood cells used and less patients transfused [94]. The general consensus is that the underlying cause of the anemia should be determined and treated if possible in order to minimize the risk of transfusion-related PRC $[64,95,96]$.

\section{Procedure Factors}

General Anesthesia versus Sedation

In adults, general anesthesia (GA) has been shown to be an independent risk factor for PRCs, a risk which is decreased with regional anesthesia [60,76,77].

The APRICOT study demonstrated a 3-fold increase in the risk of severe respiratory critical events (PRCs) with GA versus sedation (Relative Risk 3.15) [10]. In children, the risk of PRCs has been shown to be higher with midazolam premedication, desflurane (versus sevoflurane), and in those whose vocal cords were sprayed with lignocaine [14]. Inhalation anesthesia increases the risk of laryngospasm more than monitored anesthesia care with propofol [14]. Endotracheal intubation increases the risk of coughing and bronchospasm and poses a higher risk of PRCs as compared to anesthesia delivered by face mask, particularly in the asthmatic and recent URI at-risk population $[14,18,88]$. von Ungern-Sternberg et al., found that the insertion of a cuffed versus uncuffed endotracheal tube should be carefully considered in children. The uncuffed endotracheal tube increases the risk of laryngospasm (10 vs 3\%) and stridor ( $4 \%$ versus $0 \%$ ) [14].

There has been no reported difference in extubation techniques relative to PRCs. Deep versus awake extubations have similar rates of PRC, despite the risk of coughing with concomitant oxygen desaturation, postoperative stridor and sore throat which are risks with awake extubations $[157,158]$. In general, children with difficult airway, obesity and aspiration risk should be extubated awake while consideration should be given to deep extubations in those with increased airway sensitivity (asthma, URI) [18,159].

Long-Acting Neuromuscular Blocking Drugs and Sugammadex

The role of neuromuscular blocking drugs (NMBD) and reversal has not been extensively studied in children. In adults, neostigmine has been shown to be an independent risk factor for PRC, the exact etiology of which is still unclear [7,81].

Sugammadex is a more recent neuromuscular reversal agent that specifically targets aminosteroidal NMBDs [82,83]. A systematic review of randomized controlled trials reported that sugammadex produces more rapid neuromuscular reversal with less bradycardia, as compared to neostigmine and placebo [84]. The use of a nerve stimulator is important to verify the reversal of neuromuscular blockade and has been shown to be an independent factor in decreasing the risk of PRC [81,85-87].

Anesthesiologist: Pediatric Subspecialty-Trained versus General/ Experienced versus Junior 
There is a general consensus in the literature that pediatric subspecialty training reduces the rate of PRCs $[10,16,19,75]$.

A study comparing the incidence of adverse respiratory events under the care of pediatric and non-pediatric trained anesthesiologists, reported that $80 \%$ of laryngospasm ( 23 out of 29 cases) and $80 \%$ of airway obstruction ( 47 out of 58 cases) occurred when a specialized pediatric anesthesiologist was not present. PRCs were approximately twice as frequent when the anesthesia provider was an anesthesia physician trainee [16]. The PeDI airway registry reports that in cases with five endotracheal intubation attempts, pediatric anesthesiologists were responsible for $44 \%$ of the successful attempts despite making the first airway attempt in $21 \%$. The recommendations were that after a failed first attempt at intubation by a trainee or less experienced airway provider, there should be rapid consideration given to switching providers and giving the airway to the most experienced [74].

A large review of institutional audits, closed claims, and large-scale studies on pediatric perioperative cardiac arrest, suggested that for children $<3$ years age, the risks of minor and major morbidities decrease in those with significant experience caring for this age group. Those with additional training or focused expertise in pediatric airway management, vascular access and management of massive hemorrhage are less likely to suffer pediatric perioperative cardiac arrests as compared to their less experienced peers [73].

Open versus Laparoscopic

In adults, laparoscopic surgery tends to reduce postoperative respiratory dysfunction. For laparoscopic cholecystectomy (LC), postoperative forced vital capacity (FVC) dropped to $73 \%$ of preoperative versus $52 \%$ for open cholecystectomy (OC). Forced expiratory volume (FEV1) dropped to $53 \%$ and $72 \%$ of baseline preoperative function for OC versus LC, respectively [89].

A meta-analysis of randomized clinical trials demonstrated that laparoscopic inguinal hernia repair, despite the longer surgical time, had earlier hospital discharge, faster return to baseline function and work, and significantly fewer postoperative complications than open repair [90]. More recent laparoscopic studies support these findings. Laparoscopic splenectomies, despite longer operating times, are associated with reduced morbidity and fewer PRCs [91].

To date, there have been no comparative studies done in pediatrics, for difference in PRC. The National Surgical Quality Improvement Project reported that in patients $<21$ years, laparoscopic proctocolectomy despite having a longer operating time and increased risk of surgical infection, had shorter postoperative hospital length of stay and reduced risk of superficial surgical site infections (SSI) [92].

The decision and choice to perform open versus laparoscopic procedures should be carefully weighed, considering patient acuity, skill of surgeon, pre-existing pulmonary status and balancing these factors with the increased risk of PRCs with longer surgical times. Longer surgical time is a known risk $[10,11,78-80]$.

Mechanical Ventilation Strategy

Intraoperative ventilation strategy designed to protect pulmonary function is critical to minimizing patient risk. Although the recommendations were drawn from adults, they are logically applicable to pediatric patients. Moderate to high positive end-expiratory pressure [PEEP], low tidal volume, peak inspiratory pressure [PIP] $<30 \mathrm{cmH} 2 \mathrm{O}$, and avoidance of high $\mathrm{FiO} 2$ are all effective strategies, adopted from ARDS experience, in the prevention of PRCs in perioperative medicine [97-102].

Moderate to High Peep

While the use of moderate to high PEEP is broadly accepted and common practice in pediatric ICUs, this may not translate to the operating room environment as adult studies suggest that low tidal volumes with moderate PEEP (6-8 cm H2O), may reduce PRCs. There is actually some concern that high PEEP may be harmful in adults $[103,104]$. The PROVHILO study was a randomized control trial (RCT) that compared high PEEP $(12 \mathrm{~cm} \mathrm{H2O})$ combined with low tidal volume and recruitment maneuver (RM) versus low tidal volume, low PEEP $(\leq 2 \mathrm{~cm} \mathrm{H2O})$ without RM. The high PEEP group suffered hemodynamic consequences and a $40 \%$ rate of PRCs. The low PEEP group did not manifest 
hemodynamic compromise and had a similar PRC rate of 39\% [104]. Fluid resuscitation prior to high PEEP and RM has been shown to mitigate hemodynamic compromise associated with high PEEP [105]. A retrospective study of 64,000 ventilated adult non-cardiac surgical patients demonstrated that PEEP of $5 \mathrm{~cm} \mathrm{H} 2 \mathrm{O}$ combined with plateau pressure of $\leq 16 \mathrm{~cm} \mathrm{H2O}$, had fewer PRCs than zero PEEP [101].

Future studies are needed, specifically for the pediatric population, to determine the relationship between tidal volume, PEEP and PRC [100,102,106].

While the optimal PEEP is not exactly known, the current available adult studies do support the use of some level of moderate PEEP for the prevention of atelectasis and should be considered for pediatric patients without lung disease, reserving high PEEP for those with pulmonary pathology [24,107-114].

Low Tidal Volume

The data on low tidal volume in pediatric surgical patients is sparse and does not provide definitive guidance. A meta-analysis of observational studies in mechanically ventilated children reported no relationship between tidal volume and clinical outcomes [115]. Most recommendations for tidal volume strategy in pediatrics are based on adult data which suggest tidal volume be kept $<10 \mathrm{ml} / \mathrm{kg}$ [115-121].

Peak Inspiratory Pressure (PIP) $<30 \mathrm{~cm} \mathrm{H2O}$

The maintenance of PIP $<30 \mathrm{~cm} \mathrm{H} 2 \mathrm{O}$ is now common practice in pediatric surgical patients, like in adults, as adopted from ARDS network recommendations $[99,122]$.

Avoidance of High FiO2

In general, the intraoperative $\mathrm{FiO} 2$ is kept to the minimum required for maintenance of sufficient oxygenation (oxygen saturation of 92\% and above) [123-125]. Critical care literature has demonstrated worsened lung function with excessive oxygen supplementation in mechanically ventilated patients with acute lung injury [126]. In neonatal medicine, the oxidative stress of hyperoxia is responsible for significant end organ injuries to the lungs (bronchopulmonary dysplasia), eyes and brain [25,127-129]. Although the mechanism of pulmonary injury in the neonates is not clearly established, in the geriatric population, hyperoxia triggers pro-inflammatory cytokines that lead to permanent destruction of elastic fibers of the lungs [25]. A current recommendation is that oxygen delivery be tailored to the patient and procedure. Although $\mathrm{FiO} 280 \%$ may be used for induction and emergence phases, a $\mathrm{FiO} 2$ of $25-35 \%$ for infants and children, $60-80 \%$ for middle-aged, and $30-40 \%$ for elderly patients is recommended for the maintenance phase [25].

\section{Postoperative Respiratory Concerns}

Tools to assess the risk of postoperative respiratory failure.

The prediction of postoperative respiratory failure is an important focus of study as it has significant impact on healthcare costs, morbidity and mortality $[1,2,4,160,161]$. Four risk prediction tools have been developed to stratify the risk of postoperative respiratory failure. Although only one of the tools has been validated in children, understanding the other three tools is important and may have applications in pediatric care.

\subsection{Prediction Tool to Determine the Need for and the Duration of Use of Postoperative Oxygen Therapy}

This is the only pediatric prediction tool. It was developed from a case-control study of 9820 children ( $<15$ years of age) who underwent GA between 2010 and 2013 in a tertiary hospital in Thailand. The primary outcomes were the need for and duration of postoperative oxygen therapy. Risk scores were classified into high (score $\geq 12$ ), intermediate (8-11), or low $(\leq 7)$ risk groups. The tool demonstrated high predictive ability. The common risk factors for oxygen requirement postoperatively were probable difficult airway, ASA physical status $\geq 3$, and surgeries involving the airway, thorax, and abdomen [162].

\subsection{The Assess Respiratory Risk in Surgical Patients in Catalonia Score (ARISCAT)}

The ARSICAT score assesses seven easily obtainable clinical factors: age (adult patients age 55 to 80 years), preoperative oxygen saturation in room air, respiratory infection in the last 
month, preoperative anemia, upper abdominal or intrathoracic surgical incision, duration of surgery, and emergency procedures. This scoring tool is validated to be able to stratify risk of PRCs into three levels-low risk ( $<26$ points), moderate risk ( $26-44$ points), and high risk ( $>45$ points) [60]. The definitions of PRCs used for the ARISCAT study were developed from the 2015 European joint task force guidelines for perioperative outcome (EPCO): respiratory failure, suspected pulmonary infection, pleural effusion, atelectasis, pneumothorax, bronchospasm and aspiration pneumonia [9]. This tool has not been validated in children.

\subsection{GUPTA Risk Calculator Predicting Postoperative Respiratory Failure}

The American College of Surgeons National Surgical Quality Improvement Program (NSQIP) reviewed a multicenter prospective dataset from 2007 to 2008 to elicit the preoperative factors that correlate with increased risk of postoperative respiratory failure. Gupta et al. then used these factors to develop and validate a risk calculator to predict postoperative respiratory failure. The preoperative factors found to be associated with increased risk of postoperative respiratory failure were type of surgery, emergency case, dependent with functional status, sepsis, and higher ASA class [163]. This risk calculator has not been validated in children.

\subsection{Score for Prediction of Postoperative Respiratory Complications (SPORC)}

The SPORC tool was developed and validated from electronic records and billing information of adults with the goal of predicting the risk of postoperative reintubation (within the immediate 3 postoperative days) with a subsequent need for mechanical ventilator support. An 11-point score was developed from independent predictors. The factors that were found to predict postoperative reintubation were: ASA score of $\geq 3$, emergency surgery, high-risk surgical service, history of congestive heart failure, and chronic pulmonary disease [164].

\subsection{Postoperative Pain Management}

The first $24 \mathrm{~h}$ of the postoperative phase is the period with the highest likelihood of respiratory failure associated with the administration of Analgesics—specifically opioids [165-167]. Studies have demonstrated that neuraxial analgesia, when combined with GA, reduces the risk of PRCs (hypoventilation, postoperative ventilation, postoperative reintubation and postoperative pneumonia) when compared to opioids alone, especially in patients with underlying respiratory pathology [92,165-169].

Patients with obesity-related OSA are known to have higher rates of postoperative hypoventilation and oxygen desaturation due to hypersensitivity to opioids; therefore, opioid-sparing techniques are highly recommended for postoperative pain management in patients with obesity [170-172].

Adequate pain control is necessary to prevent splinting and the development of atelectasis and desaturation [173].

\subsection{Physical Therapy: EARLY Mobilization and Chest Physiotherapy}

Early mobilization has been shown to be feasible and safe in critically ill children, however, the efficacy of mobilization in shortening duration of mechanical ventilation and ICU duration of stay remains unclear [174,175].

Chest physiotherapy has not been shown to reduce the rate of PRCs [173]. The I COUGH initiative (incentive spirometry, coughing and deep breathing, oral care, understanding, getting out of bed, and head of bed elevation) has been widely instituted in ICUs. Preliminary data from this initiative suggests that the rate of pneumonia and unplanned reintubation in postoperative adults is lowered $[173,176]$. The role of combining adequate pain management, physical therapy, early mobilization and good oral care in order to minimize postoperative PRCs will require further large scale studies [173].

The applicability of this I COUGH initiative to the pediatric population warrants future study. 


\section{Conclusions}

Perioperative respiratory complications in pediatric patients are quite common and lead to increase in hospital length of stay and health care costs. While there are perioperative risk prediction tools that measure PRC risk, few are pediatric-specific, and they can be quite difficult to apply in clinical practice. Routine preoperative laboratory assessment should be reserved for those whose medical or family history, review of systems or impending procedure, warrants focused preoperative testing. The role of preoperative oxygen saturation and ABG has yet to be determined for the pediatric patient, though both have been shown to be helpful in predicting the risk of developing PRCs in adults. Early recognition of a difficult airway with rapid transition from direct to indirect laryngoscopy has been shown to be effective in a pediatric difficult airway situation. Children with significant comorbidities and an ASA classification $\geq 3$ have a higher likelihood of critical events in the perioperative period. Children with asthma should be optimized from a respiratory standpoint prior to surgery. Obstructive sleep apnea also poses an inherent risk for PRCs in children. A detailed assessment of diagnostic sleep studies, home monitors (pulse oximeter, apnea monitor) as well as non-surgical home medical management (supplemental oxygen, CPAP, BiPAP, preferred sleep position) should be obtained and should be made available for in-hospital use during the immediate postoperative period. There is a significantly increased risk of PRCs in children with acute or recent ( $<2$ weeks) URI. The precise time of risk following a URI remains unclear though the consensus amongst pediatric anesthesiologists is that elective surgery be delayed until 2-3 weeks following resolution of URI symptoms. Childhood obesity is linked to many major comorbidities such as hypertension, type II diabetes, heart disease, hyperlipidemia, and asthma and it increases the likelihood of PRCs in children, like adults. Both passive and active smoking increase the risk of PRCs in children and preoperative screening for vaping/e-cigarette use and its potentially associated symptoms amongst early teens/adolescents is necessary given the increased prevalence of vaping in that age group. The underlying cause of anemia should be determined and treated if possible, to minimize the risk of transfusion-related PRC. It is important to note that that pediatric subspecialty training reduces the rate of PRCs. Intraoperative ventilation strategy designed to protect pulmonary function is critical to minimizing patient risk. Moderate to high PEEP, low tidal volume, PIP $<30 \mathrm{~cm} \mathrm{H2O}$, and avoidance of high $\mathrm{FiO} 2$ are all effective strategies, adopted from ARDS experience, in the prevention of PRCs in perioperative medicine. Neuraxial analgesia, when combined with GA, reduces the risk of PRCs when compared to opioids alone especially in patients with underlying respiratory pathology and obesity-related OSA. Vigilance to the various factors, both modifiable and non-modifiable, that are associated with the increased risk of PRCs should support detailed preoperative assessment, more accurate informed consent, optimized intraoperative management strategy and improved allocation of clinical resources in order to decrease morbidity and mortality.

Author Contributions: Reviewing the relevant literature: C.E. and K.P.M.; Manuscript preparation: C.E. and K.P.M.; Approval of final manuscript and attestation to data integrity: C.E. and K.P.M. All authors have read and agreed to the published version of the manuscript.

Funding: This research received no external funding.

Acknowledgments: The authors acknowledge Kimberly Manning, BA, Department of Anesthesiology, Critical Care and Pain Medicine at Boston Children's Hospital, Boston, MA for her highly valued assistance in the preparation of this manuscript.

Conflicts of Interest: The authors declare no conflict of interest. 


\section{Abbreviations}

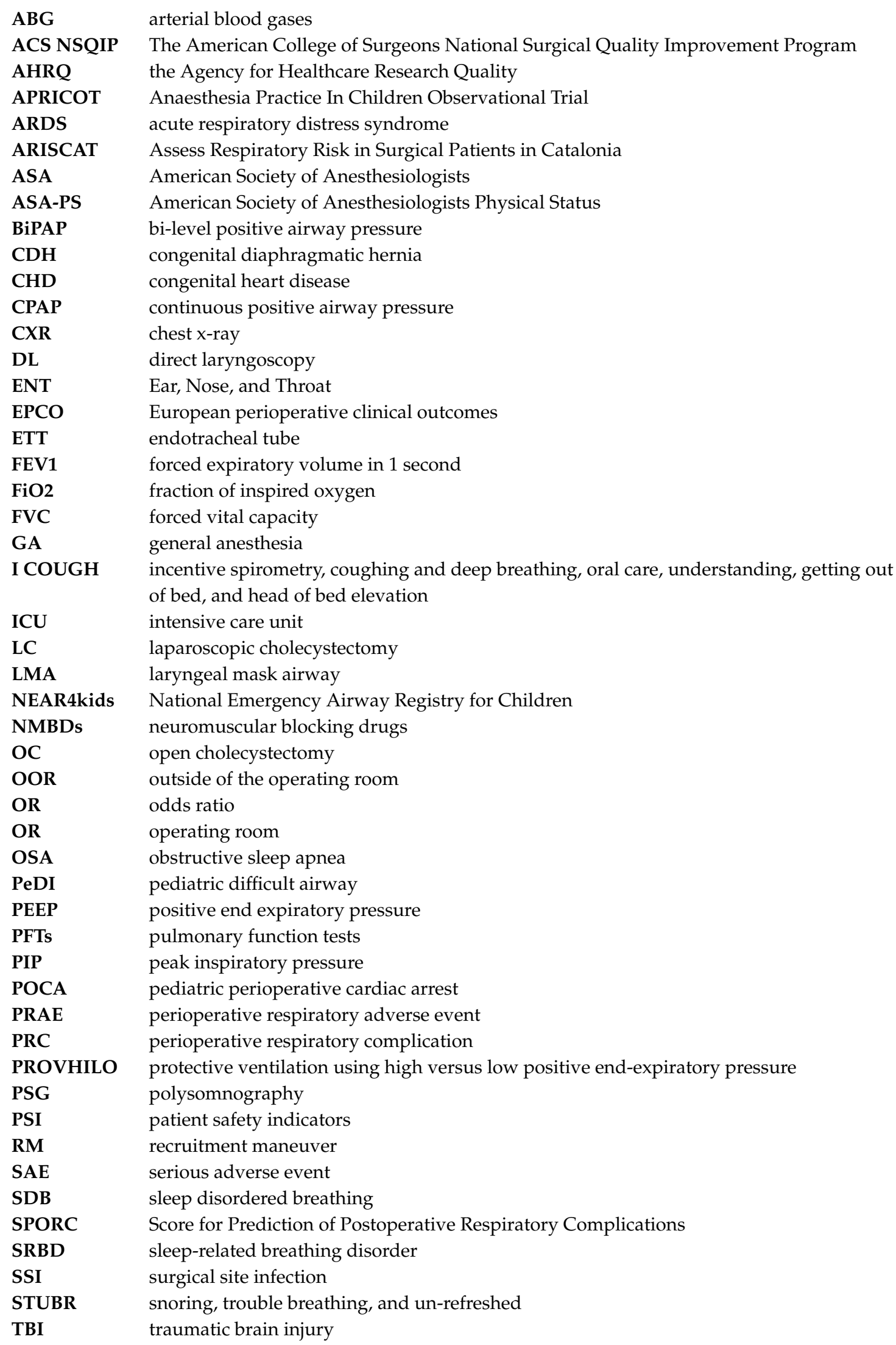


TEF tracheoesophageal fistula

URI upper respiratory illness

WUS wake-up safe

\section{References}

1. Kronman, M.P.; Hall, M.; Slonim, A.D.; Shah, S.S. Charges and lengths of stay attributable to adverse patient-care events using pediatric-specific quality indicators: A multicenter study of freestanding children's hospitals. Pediatrics 2008, 121, e1653-e1659. [CrossRef] [PubMed]

2. Miller, M.R.; Zhan, C. Pediatric patient safety in hospitals: A national picture in 2000. Pediatrics 2004, 113, 1741-1746. [CrossRef] [PubMed]

3. Oofuvong, M.; Geater, A.F.; Chongsuvivatwong, V.; Chanchayanon, T.; Sriyanaluk, B.; Saefung, B.; Nuanjun, K. Excess costs and length of hospital stay attributable to perioperative respiratory events in children. Anesth. Analg. 2015, 120, 411-419. [CrossRef] [PubMed]

4. Ramachandran, S.K.; Nafiu, O.O.; Ghaferi, A.; Tremper, K.K.; Shanks, A.; Kheterpal, S. Independent predictors and outcomes of unanticipated early postoperative tracheal intubation after nonemergent, noncardiac surgery. Anesthesiology 2011, 115, 44-53. [CrossRef] [PubMed]

5. Davenport, D.L.; Henderson, W.G.; Khuri, S.F.; Mentzer, R.M., Jr. Preoperative risk factors and surgical complexity are more predictive of costs than postoperative complications: A case study using the National Surgical Quality Improvement Program (NSQIP) database. Ann. Surg. 2005, 242, 463-468. [CrossRef]

6. Subramanyam, R.; Yeramaneni, S.; Hossain, M.M.; Anneken, A.M.; Varughese, A.M. Perioperative Respiratory Adverse Events in Pediatric Ambulatory Anesthesia: Development and Validation of a Risk Prediction Tool. Anesth. Analg. 2016, 122, 1578-1585. [CrossRef]

7. Miskovic, A.; Lumb, A.B. Postoperative pulmonary complications. Br. J. Anaesth. 2017, 118, 317-334. [CrossRef]

8. Luhmann, S.J.; Furdock, R. Preoperative Variables Associated With Respiratory Complications After Pediatric Neuromuscular Spine Deformity Surgery. Spine Deform. 2019, 7, 107-111. [CrossRef]

9. Jammer, I.; Wickboldt, N.; Sander, M.; Smith, A.; Schultz, M.J.; Pelosi, P.; Leva, B.; Rhodes, A.; Hoeft, A.; Walder, B.; et al. Standards for definitions and use of outcome measures for clinical effectiveness research in perioperative medicine: European Perioperative Clinical Outcome (EPCO) definitions: A statement from the ESA-ESICM joint taskforce on perioperative outcome measures. Eur. J. Anaesthesiol 2015, 32, 88-105. [CrossRef]

10. Habre, W.; Disma, N.; Virag, K.; Becke, K.; Hansen, T.G.; Johr, M.; Leva, B.; Morton, N.S.; Vermeulen, P.M.; Zielinska, M.; et al. Incidence of severe critical events in paediatric anaesthesia (APRICOT): A prospective multicentre observational study in 261 hospitals in Europe. Lancet Respir. Med. 2017, 5, 412-425. [CrossRef]

11. Schleelein, L.E.; Vincent, A.M.; Jawad, A.F.; Pruitt, E.Y.; Kreher, G.D.; Rehman, M.A.; Goebel, T.K.; Cohen, D.E.; Cook-Sather, S.D. Pediatric perioperative adverse events requiring rapid response: A retrospective case-control study. Paediatr. Anaesth. 2016, 26, 734-741. [CrossRef] [PubMed]

12. de Graaff, J.C.; Sarfo, M.C.; van Wolfswinkel, L.; van der Werff, D.B.; Schouten, A.N. Anesthesia-related critical incidents in the perioperative period in children; a proposal for an anesthesia-related reporting system for critical incidents in children. Paediatr. Anaesth. 2015, 25, 621-629. [CrossRef] [PubMed]

13. Kurth, C.D.; Tyler, D.; Heitmiller, E.; Tosone, S.R.; Martin, L.; Deshpande, J.K. National pediatric anesthesia safety quality improvement program in the United States. Anesth. Analg. 2014, 119, 112-121. [CrossRef] [PubMed]

14. von Ungern-Sternberg, B.S.; Boda, K.; Chambers, N.A.; Rebmann, C.; Johnson, C.; Sly, P.D.; Habre, W. Risk assessment for respiratory complications in paediatric anaesthesia: A prospective cohort study. Lancet 2010, 376, 773-783. [CrossRef]

15. Bhananker, S.M.; Ramamoorthy, C.; Geiduschek, J.M.; Posner, K.L.; Domino, K.B.; Haberkern, C.M.; Campos, J.S.; Morray, J.P. Anesthesia-related cardiac arrest in children: Update from the Pediatric Perioperative Cardiac Arrest Registry. Anesth. Analg. 2007, 105, 344-350. [CrossRef]

16. Mamie, C.; Habre, W.; Delhumeau, C.; Argiroffo, C.B.; Morabia, A. Incidence and risk factors of perioperative respiratory adverse events in children undergoing elective surgery. Paediatr. Anaesth. 2004, 14, 218-224. [CrossRef] 
17. Murat, I.; Constant, I.; Maud'huy, H. Perioperative anaesthetic morbidity in children: A database of 24,165 anaesthetics over a 30-month period. Paediatr. Anaesth. 2004, 14, 158-166. [CrossRef]

18. Budic, I.; Simic, D. Risk factors for respiratory adverse events during general anesthesia in children. Med. Biol. 2004, 11521, 118-122.

19. Tay, C.L.; Tan, G.M.; Ng, S.B. Critical incidents in paediatric anaesthesia: An audit of 10,000 anaesthetics in Singapore. Paediatr. Anaesth. 2001, 11,711-718. [CrossRef]

20. Morris, L.G.; Lieberman, S.M.; Reitzen, S.D.; Edelstein, D.R.; Ziff, D.J.; Katz, A.; Komisar, A. Characteristics and outcomes of malpractice claims after tonsillectomy. Otolaryngol. Head Neck Surg. Off. J. Am. Acad. Otolaryngol. Head Neck Surg. 2008, 138, 315-320. [CrossRef]

21. Tait, A.R.; Voepel-Lewis, T.; Christensen, R.; O'Brien, L.M. The STBUR questionnaire for predicting perioperative respiratory adverse events in children at risk for sleep-disordered breathing. Paediatr. Anaesth. 2013, 23, 510-516. [CrossRef] [PubMed]

22. Lee, L.K.; Bernardo, M.K.L.; Grogan, T.R.; Elashoff, D.A.; Ren, W.H.P. Perioperative respiratory adverse event risk assessment in children with upper respiratory tract infection: Validation of the COLDS score. Paediatr. Anaesth. 2018, 28, 1007-1014. [CrossRef] [PubMed]

23. Dones, F.; Foresta, G.; Russotto, V. Update on perioperative management of the child with asthma. Pediatr. Rep. 2012, 4, e19. [CrossRef] [PubMed]

24. Kneyber, M.C.J.; de Luca, D.; Calderini, E.; Jarreau, P.H.; Javouhey, E.; Lopez-Herce, J.; Hammer, J.; Macrae, D.; Markhorst, D.G.; Medina, A.; et al. Recommendations for mechanical ventilation of critically ill children from the Paediatric Mechanical Ventilation Consensus Conference (PEMVECC). Intensive Care Med. 2017, 43, 1764-1780. [CrossRef] [PubMed]

25. Habre, W.; Peták, F. Perioperative use of oxygen: Variabilities across age. Br. J. Anaesth. 2014, 113 (Suppl. 2), ii26-ii36. [CrossRef]

26. Grover, T.R.; Brozanski, B.S.; Barry, J.; Zaniletti, I.; Asselin, J.M.; Durand, D.J.; Short, B.L.; Pallotto, E.K.; Dykes, F.; Reber, K.M.; et al. High surgical burden for infants with severe chronic lung disease (sCLD). J. Pediatric Surg. 2014, 49, 1202-1205. [CrossRef]

27. von Ungern-Sternberg, B.S.; Boda, K.; Schwab, C.; Sims, C.; Johnson, C.; Habre, W. Laryngeal mask airway is associated with an increased incidence of adverse respiratory events in children with recent upper respiratory tract infections. Anesthesiology 2007, 107, 714-719. [CrossRef]

28. Rachel Homer, J.; Elwood, T.; Peterson, D.; Rampersad, S. Risk factors for adverse events in children with colds emerging from anesthesia: A logistic regression. Paediatr. Anaesth. 2007, 17, 154-161. [CrossRef]

29. Tait, A.R.; Malviya, S.; Voepel-Lewis, T.; Munro, H.M.; Siewert, M.; Pandit, U.A. Risk Factors for Perioperative Adverse Respiratory Events in Children with Upper Respiratory Tract Infections. Anesth. J. Am. Soc. Anesth. 2001, 95, 299-306.

30. Lee, S.; Reddington, E.; Koutsogiannaki, S.; Hernandez, M.R.; Odegard, K.C.; DiNardo, J.A.; Yuki, K. Incidence and Risk Factors for Perioperative Cardiovascular and Respiratory Adverse Events in Pediatric Patients With Congenital Heart Disease Undergoing Noncardiac Procedures. Anesth. Analg. 2018, 127, 724-729. [CrossRef]

31. Parnis, S.J.; Barker, D.S.; Van Der Walt, J.H. Clinical predictors of anaesthetic complications in children with respiratory tract infections. Paediatr. Anaesth. 2001, 11, 29-40. [CrossRef] [PubMed]

32. Skolnick, E.T.; Vomvolakis, M.A.; Buck, K.A.; Mannino, S.F.; Sun, L.S. Exposure to environmental tobacco smoke and the risk of adverse respiratory events in children receiving general anesthesia. Anesthesiology 1998, 88, 1144-1153. [CrossRef] [PubMed]

33. Ehrlich, R.; Kattan, M.; Godbold, J.; Saltzberg, D.S.; Grimm, K.T.; Landrigan, P.J.; Lilienfeld, D.E. Childhood asthma and passive smoking. Urinary cotinine as a biomarker of exposure. Am. Rev. Respir. Dis. 1992, 145, 594-599. [CrossRef]

34. Willers, S.; Svenonius, E.; Skarping, G. Passive smoking and childhood asthma. Urinary cotinine levels in children with asthma and in referents. Allergy 1991, 46, 330-334. [CrossRef] [PubMed]

35. Murray, A.B.; Morrison, B.J. The effect of cigarette smoke from the mother on bronchial responsiveness and severity of symptoms in children with asthma. J. Allergy Clin. Immunol. 1986, 77, 575-581. [CrossRef]

36. Mills, E.; Eyawo, O.; Lockhart, I.; Kelly, S.; Wu, P.; Ebbert, J.O. Smoking cessation reduces postoperative complications: A systematic review and meta-analysis. Am. J. Med. 2011, 124, 144-154. [CrossRef] 
37. Wong, J.; Lam, D.P.; Abrishami, A.; Chan, M.T.; Chung, F. Short-term preoperative smoking cessation and postoperative complications: A systematic review and meta-analysis. Can. J. Anaesth. J. Can. D'anesthesie 2012, 59, 268-279. [CrossRef] [PubMed]

38. Lee, S.M.; Landry, J.; Jones, P.M.; Buhrmann, O.; Morley-Forster, P. Long-term quit rates after a perioperative smoking cessation randomized controlled trial. Anesth. Analg. 2015, 120, 582-587. [CrossRef]

39. Shi, Y.; Warner, D.O. Surgery as a teachable moment for smoking cessation. Anesthesiology 2010, 112, $102-107$. [CrossRef]

40. McRobbie, H.; Bullen, C.; Hartmann-Boyce, J.; Hajek, P. Electronic cigarettes for smoking cessation and reduction. Cochrane Database Syst. Rev. 2014, Cd010216. [CrossRef]

41. Miech, R.A.; Johnston, L.D.; O'Malley, P.M.; Bachman, J.G.; Schulenberg, J.E.; Patrick, M.E. Monitoring the Future National Survey Results on Drug Use, 1975-2017. Volume I, Secondary School Students. Inst. Soc. Res. 2018, 110-300. [CrossRef]

42. Layden, J.E.; Ghinai, I.; Pray, I.; Kimball, A.; Layer, M.; Tenforde, M.W.; Navon, L.; Hoots, B.; Salvatore, P.P.; Elderbrook, M.; et al. Pulmonary Illness Related to E-Cigarette Use in Illinois and Wisconsin-Final Report. N. Engl. J. Med. 2020, 382, 903-916. [CrossRef] [PubMed]

43. Matthay, M.A.; Zemans, R.L.; Zimmerman, G.A.; Arabi, Y.M.; Beitler, J.R.; Mercat, A.; Herridge, M.; Randolph, A.G.; Calfee, C.S. Acute respiratory distress syndrome. Nat. Rev. Dis. Primers 2019, 5, 18. [CrossRef]

44. Cook-Sather, S.D.; Gallagher, P.R.; Kruge, L.E.; Beus, J.M.; Ciampa, B.P.; Welch, K.C.; Shah-Hosseini, S.; Choi, J.S.; Pachikara, R.; Minger, K.; et al. Overweight/obesity and gastric fluid characteristics in pediatric day surgery: Implications for fasting guidelines and pulmonary aspiration risk. Anesth. Analg. 2009, 109, 727-736. [CrossRef] [PubMed]

45. Nafiu, O.O.; Curcio, C. Simplified table to identify overweight and obese children undergoing anesthesia. Paediatr. Anaesth. 2013, 23, 964-966. [CrossRef]

46. Mortensen, A.; Lenz, K.; Abildstrøm, H.; Lauritsen, T.L. Anesthetizing the obese child. Paediatr. Anaesth. 2011, 21, 623-629. [CrossRef]

47. Bandla, P.; Brooks, L.J.; Trimarchi, T.; Helfaer, M. Obstructive sleep apnea syndrome in children. Anesth. Clin. North Am. 2005, 23, 535-549. [CrossRef]

48. Sorof, J.M.; Turner, J.; Martin, D.S.; Garcia, K.; Garami, Z.; Alexandrov, A.V.; Wan, F.; Portman, R.J. Cardiovascular risk factors and sequelae in hypertensive children identified by referral versus school-based screening. Hypertension 2004, 43, 214-218. [CrossRef]

49. Hanevold, C.; Waller, J.; Daniels, S.; Portman, R.; Sorof, J. The effects of obesity, gender, and ethnic group on left ventricular hypertrophy and geometry in hypertensive children: A collaborative study of the International Pediatric Hypertension Association. Pediatrics 2004, 113, 328-333. [CrossRef]

50. Mannino, D.M.; Mott, J.; Ferdinands, J.M.; Camargo, C.A.; Friedman, M.; Greves, H.M.; Redd, S.C. Boys with high body masses have an increased risk of developing asthma: Findings from the National Longitudinal Survey of Youth (NLSY). Int. J. Obes. (Lond) 2006, 30, 6-13. [CrossRef]

51. Rosen, C.L.; Wang, R.; Taylor, H.G.; Marcus, C.L.; Katz, E.S.; Paruthi, S.; Arens, R.; Muzumdar, H.; Garetz, S.L.; Mitchell, R.B.; et al. Utility of symptoms to predict treatment outcomes in obstructive sleep apnea syndrome. Pediatrics 2015, 135, e662-e671. [CrossRef] [PubMed]

52. Dixon, A.E.; Holguin, F.; Sood, A.; Salome, C.M.; Pratley, R.E.; Beuther, D.A.; Celedón, J.C.; Shore, S.A. An official American Thoracic Society Workshop report: Obesity and asthma. Proc. Am. Thorac. Soc. 2010, 7, 325-335. [CrossRef] [PubMed]

53. El-Metainy, S.; Ghoneim, T.; Aridae, E.; Abdel Wahab, M. Incidence of perioperative adverse events in obese children undergoing elective general surgery. Br. J. Anaesth. 2011, 106, 359-363. [CrossRef] [PubMed]

54. Arens, R.; Muzumdar, H. Childhood obesity and obstructive sleep apnea syndrome. J. Appl. Physiol. (1985) 2010, 108, 436-444. [CrossRef]

55. Nafiu, O.O.; Reynolds, P.I.; Bamgbade, O.A.; Tremper, K.K.; Welch, K.; Kasa-Vubu, J.Z. Childhood body mass index and perioperative complications. Paediatr. Anaesth. 2007, 17, 426-430. [CrossRef]

56. Goldstein, D.J. Beneficial health effects of modest weight loss. Int. J. Obes. Relat. Metab Disord. 1992, 16, 397-415. 
57. Alzahrani, A.; Othman, N.; Bin-Ali, T.; Elfaraidi, H.; Al Mussaed, E.; Alabbas, F.; Sedick, Q.; Albatniji, F.; Alshahrani, Z.; Asiri, M.; et al. Routine Preoperative Coagulation Tests in Children Undergoing Elective Surgery or Invasive Procedures: Are They Still Necessary? Clin. Med. Insights Blood Disord. 2019, 12, 1179545x18821158. [CrossRef]

58. Almesbah, F.; Mandiwanza, T.; Kaliaperumal, C.; Caird, J.; Crimmins, D. Routine preoperative blood testing in pediatric neurosurgery. J. Neurosurg. Pediatrics 2013, 12, 615-621. [CrossRef]

59. Nieto, R.M.; De Leon, L.E.; Diaz, D.T.; Krauklis, K.A.; Fraser, C.D., Jr. Routine preoperative laboratory testing in elective pediatric cardiothoracic surgery is largely unnecessary. J. Thoracic Cardiovasc. Surg. 2017, 153, 678-685. [CrossRef]

60. Canet, J.; Gallart, L.; Gomar, C.; Paluzie, G.; Vallès, J.; Castillo, J.; Sabaté, S.; Mazo, V.; Briones, Z.; Sanchis, J. Prediction of postoperative pulmonary complications in a population-based surgical cohort. Anesthesiology 2010, 113, 1338-1350. [CrossRef]

61. O'Connor, M.E.; Drasner, K. Preoperative laboratory testing of children undergoing elective surgery. Anesth. Analg. 1990, 70, 176-180. [PubMed]

62. Faraoni, D.; DiNardo, J.A.; Goobie, S.M. Relationship Between Preoperative Anemia and In-Hospital Mortality in Children Undergoing Noncardiac Surgery. Anesth. Analg. 2016, 123, 1582-1587. [CrossRef] [PubMed]

63. Goobie, S.M.; Faraoni, D.; Zurakowski, D.; DiNardo, J.A. Association of Preoperative Anemia with Postoperative Mortality in Neonates. JAMA Pediatr. 2016, 170, 855-862. [CrossRef] [PubMed]

64. Kedir, H.; Miller, R.; Syed, F.; Hakim, M.; Walia, H.; Tumin, D.; McKee, C.; Tobias, J.D. Association between anemia and postoperative complications in infants undergoing pyloromyotomy. J. Pediatric Surg. 2019, 54, 2075-2079. [CrossRef]

65. Mazo, V.; Sabaté, S.; Canet, J.; Gallart, L.; de Abreu, M.G.; Belda, J.; Langeron, O.; Hoeft, A.; Pelosi, P. Prospective external validation of a predictive score for postoperative pulmonary complications. Anesthesiology 2014, 121, 219-231. [CrossRef]

66. McAlister, F.A.; Bertsch, K.; Man, J.; Bradley, J.; Jacka, M. Incidence of and risk factors for pulmonary complications after nonthoracic surgery. Am. J. Respir. Crit. Care Med. 2005, 171, 514-517. [CrossRef]

67. Kovacevic, M.; Goranovic, T.; Markic, A.; Jelisavac, M.; Zuric, I.; Tonkovic, D. Usefulness of routine chest $\mathrm{X}$-ray in preoperative evaluation of patients undergoing non-cardiopulmonary surgery: A prospective observational study: 1AP5-5. Eur. J. Anaesthesiol (EJA) 2012, 29, 16. [CrossRef]

68. Archer, C.; Levy, A.R.; McGregor, M. Value of routine preoperative chest X-rays: A meta-analysis. Can. J. Anaesth. J. Can. D'Anesthesie 1993, 40, 1022-1027. [CrossRef]

69. Tape TG, M.A. Diagnostic Decision: The Utility of Routine Chest Radiographs. Ann. Intern. Med. 1986, 104, 663-670. [CrossRef]

70. Kerr, I.H. The preoperative chest X-ray. Br. J. Anaesth. 1974, 46, 558-563. [CrossRef]

71. Burjek, N.E.; Rao, K.E.; Wieser, J.P.; Evans, M.A.; Toaz, E.E.; Balmert, L.C.; Sarwark, J.F.; Jagannathan, N. Preoperative Pulmonary Function Test Results Are Not Associated With Postoperative Intubation in Children Undergoing Posterior Spinal Fusion for Scoliosis: A Retrospective Observational Study. Anesth. Analg. 2019, 129, 184-191. [CrossRef] [PubMed]

72. Fisher, B.W.; Majumdar, S.R.; McAlister, F.A. Predicting pulmonary complications after nonthoracic surgery: A systematic review of blinded studies. Am. J. Med. 2002, 112, 219-225. [CrossRef]

73. Paterson, N.; Waterhouse, P. Risk in pediatric anesthesia. Pediatric Anesth. 2011, 21, 848-857. [CrossRef] [PubMed]

74. Fiadjoe, J.E.; Nishisaki, A.; Jagannathan, N.; Hunyady, A.I.; Greenberg, R.S.; Reynolds, P.I.; Matuszczak, M.E.; Rehman, M.A.; Polaner, D.M.; Szmuk, P.; et al. Airway management complications in children with difficult tracheal intubation from the Pediatric Difficult Intubation (PeDI) registry: A prospective cohort analysis. Lancet Respir. Med. 2016, 4, 37-48. [CrossRef]

75. Auroy, Y.; Ecoffey, C.; Messiah, A.; Rouvier, B. Relationship between complications of pediatric anesthesia and volume of pediatric anesthetics. Anesth. Analg. 1997, 84, 234-235. [CrossRef] [PubMed]

76. Arozullah, A.M.; Khuri, S.F.; Henderson, W.G.; Daley, J. Development and validation of a multifactorial risk index for predicting postoperative pneumonia after major noncardiac surgery. Ann. Int. Med. 2001, 135, 847-857. [CrossRef] [PubMed] 
77. Guay, J.; Choi, P.; Suresh, S.; Albert, N.; Kopp, S.; Pace, N.L. Neuraxial blockade for the prevention of postoperative mortality and major morbidity: An overview of Cochrane systematic reviews. Cochrane Database Syst. Rev. 2014, 2014, Cd010108. [CrossRef]

78. Cheng, H.; Clymer, J.W.; Po-Han Chen, B.; Sadeghirad, B.; Ferko, N.C.; Cameron, C.G.; Hinoul, P. Prolonged operative duration is associated with complications: A systematic review and meta-analysis. J. Surg. Res. 2018, 229, 134-144. [CrossRef]

79. Brooks-Brunn, J.A. Predictors of postoperative pulmonary complications following abdominal surgery. Chest 1997, 111, 564-571. [CrossRef]

80. McAlister, F.A.; Khan, N.A.; Straus, S.E.; Papaioakim, M.; Fisher, B.W.; Majumdar, S.R.; Gajic, O.; Daniel, M.; Tomlinson, G. Accuracy of the preoperative assessment in predicting pulmonary risk after nonthoracic surgery. Am. J. Respir. Crit. Care Med. 2003, 167, 741-744. [CrossRef]

81. Grosse-Sundrup, M.; Henneman, J.P.; Sandberg, W.S.; Bateman, B.T.; Uribe, J.V.; Nguyen, N.T.; Ehrenfeld, J.M.; Martinez, E.A.; Kurth, T.; Eikermann, M. Intermediate acting non-depolarizing neuromuscular blocking agents and risk of postoperative respiratory complications: Prospective propensity score matched cohort study. BMJ 2012, 345, e6329. [CrossRef] [PubMed]

82. Suy, K.; Morias, K.; Cammu, G.; Hans, P.; van Duijnhoven, W.G.; Heeringa, M.; Demeyer, I. Effective reversal of moderate rocuronium- or vecuronium-induced neuromuscular block with sugammadex, a selective relaxant binding agent. Anesthesiology 2007, 106, 283-288. [CrossRef]

83. Rex, C.; Bergner, U.A.; Pühringer, F.K. Sugammadex: A selective relaxant-binding agent providing rapid reversal. Curr. Opin. Anaesthesiol 2010, 23, 461-465. [CrossRef] [PubMed]

84. Liu, G.; Wang, R.; Yan, Y.; Fan, L.; Xue, J.; Wang, T. The efficacy and safety of sugammadex for reversing postoperative residual neuromuscular blockade in pediatric patients: A systematic review. Sci. Rep. 2017, 7, 5724. [CrossRef] [PubMed]

85. Sasaki, N.; Meyer, M.J.; Malviya, S.A.; Stanislaus, A.B.; MacDonald, T.; Doran, M.E.; Igumenshcheva, A.; Hoang, A.H.; Eikermann, M. Effects of neostigmine reversal of nondepolarizing neuromuscular blocking agents on postoperative respiratory outcomes: A prospective study. Anesthesiology 2014, 121, 959-968. [CrossRef]

86. Todd, M.M.; Hindman, B.J. The Implementation of Quantitative Electromyographic Neuromuscular Monitoring in an Academic Anesthesia Department: Follow-Up Observations. Anesth. Analg. 2015, 121, 836-838. [CrossRef]

87. Brull, S.J.; Kopman, A.F. Current Status of Neuromuscular Reversal and Monitoring: Challenges and Opportunities. Anesthesiology 2017, 126, 173-190. [CrossRef]

88. Bordet, F.; Allaouchiche, B.; Lansiaux, S.; Combet, S.; Pouyau, A.; Taylor, P.; Bonnard, C.; Chassard, D. Risk factors for airway complications during general anaesthesia in paediatric patients. Paediatr. Anaesth. 2002, 12, 762-769. [CrossRef]

89. Frazee, R.C.; Roberts, J.W.; Okeson, G.C.; Symmonds, R.E.; Snyder, S.K.; Hendricks, J.C.; Smith, R.W. Open versus laparoscopic cholecystectomy. A comparison of postoperative pulmonary function. Ann. Surg. 1991, 213, 651-653. [CrossRef]

90. Memon, M.A.; Cooper, N.J.; Memon, B.; Memon, M.I.; Abrams, K.R. Meta-analysis of randomized clinical trials comparing open and laparoscopic inguinal hernia repair. Br. J. Surg. 2003, 90, 1479-1492. [CrossRef]

91. Winslow, E.R.; Brunt, L.M. Perioperative outcomes of laparoscopic versus open splenectomy: A meta-analysis with an emphasis on complications. Surgery 2003, 134, 647-653. [CrossRef]

92. Kauffman, J.D.; Snyder, C.W.; Danielson, P.D.; Chandler, N.M. 30-Day Outcomes of Laparoscopic Versus Open Total Proctocolectomy with Ileoanal Anastomosis in Children and Young Adults: A Combined Analysis of the National Surgical Quality Improvement Project Pediatric and Adult Databases. J. Laparoendosc. Adv. Surg. Tech. A 2019, 29, 402-408. [CrossRef] [PubMed]

93. Nafiu, O.O.; Ramachandran, S.K.; Ackwerh, R.; Tremper, K.K.; Campbell, D.A., Jr.; Stanley, J.C. Factors associated with and consequences of unplanned post-operative intubation in elderly vascular and general surgery patients. Eur. J. Anaesthesiol 2011, 28, 220-224. [CrossRef]

94. Holst, L.B.; Petersen, M.W.; Haase, N.; Perner, A.; Wetterslev, J. Restrictive versus liberal transfusion strategy for red blood cell transfusion: Systematic review of randomised trials with meta-analysis and trial sequential analysis. BMJ 2015, 350, h1354. [CrossRef]

95. Clevenger, B.; Richards, T. Pre-operative anaemia. Anaesthesia 2015, 70 (Suppl. 1), e26-e28. [CrossRef] 
96. Kotzé, A.; Harris, A.; Baker, C.; Iqbal, T.; Lavies, N.; Richards, T.; Ryan, K.; Taylor, C.; Thomas, D. British Committee for Standards in Haematology Guidelines on the Identification and Management of Pre-Operative Anaemia. Br. J. Haematol. 2015, 171, 322-331. [CrossRef]

97. Wanderer, J.P.; Ehrenfeld, J.M.; Epstein, R.H.; Kor, D.J.; Bartz, R.R.; Fernandez-Bustamante, A.; Vidal Melo, M.F.; Blum, J.M. Temporal trends and current practice patterns for intraoperative ventilation at U.S. academic medical centers: A retrospective study. BMC Anesth. 2015, 15, 40. [CrossRef] [PubMed]

98. Bender, S.P.; Paganelli, W.C.; Gerety, L.P.; Tharp, W.G.; Shanks, A.M.; Housey, M.; Blank, R.S.; Colquhoun, D.A.; Fernandez-Bustamante, A.; Jameson, L.C.; et al. Intraoperative Lung-Protective Ventilation Trends and Practice Patterns: A Report from the Multicenter Perioperative Outcomes Group. Anesth. Analg. 2015, 121, 1231-1239. [CrossRef] [PubMed]

99. Brower, R.G.; Matthay, M.A.; Morris, A.; Schoenfeld, D.; Thompson, B.T.; Wheeler, A. Ventilation with lower tidal volumes as compared with traditional tidal volumes for acute lung injury and the acute respiratory distress syndrome. N. Engl. J. Med. 2000, 342, 1301-1308. [CrossRef] [PubMed]

100. Futier, E.; Constantin, J.M.; Paugam-Burtz, C.; Pascal, J.; Eurin, M.; Neuschwander, A.; Marret, E.; Beaussier, M.; Gutton, C.; Lefrant, J.Y.; et al. A trial of intraoperative low-tidal-volume ventilation in abdominal surgery. N. Engl. J. Med. 2013, 369, 428-437. [CrossRef] [PubMed]

101. Ladha, K.; Vidal Melo, M.F.; McLean, D.J.; Wanderer, J.P.; Grabitz, S.D.; Kurth, T.; Eikermann, M. Intraoperative protective mechanical ventilation and risk of postoperative respiratory complications: Hospital based registry study. BMJ 2015, 351, h3646. [CrossRef] [PubMed]

102. Severgnini, P.; Selmo, G.; Lanza, C.; Chiesa, A.; Frigerio, A.; Bacuzzi, A.; Dionigi, G.; Novario, R.; Gregoretti, C.; de Abreu, M.G.; et al. Protective mechanical ventilation during general anesthesia for open abdominal surgery improves postoperative pulmonary function. Anesthesiology 2013, 118, 1307-1321. [CrossRef] [PubMed]

103. Serpa Neto, A.; Hemmes, S.N.; Barbas, C.S.; Beiderlinden, M.; Biehl, M.; Binnekade, J.M.; Canet, J.; Fernandez-Bustamante, A.; Futier, E.; Gajic, O.; et al. Protective versus Conventional Ventilation for Surgery: A Systematic Review and Individual Patient Data Meta-analysis. Anesthesiology 2015, 123, 66-78. [CrossRef]

104. Hemmes, S.N.; Gama de Abreu, M.; Pelosi, P.; Schultz, M.J. High versus low positive end-expiratory pressure during general anaesthesia for open abdominal surgery (PROVHILO trial): A multicentre randomised controlled trial. Lancet (London, UK) 2014, 384, 495-503. [CrossRef]

105. Bohm, S.H.; Thamm, O.C.; von Sandersleben, A.; Bangert, K.; Langwieler, T.E.; Tusman, G.; Strate, T.G.; Standl, T.G. Alveolar recruitment strategy and high positive end-expiratory pressure levels do not affect hemodynamics in morbidly obese intravascular volume-loaded patients. Anesth. Analg. 2009, 109, 160-163. [CrossRef] [PubMed]

106. Levin, M.A.; McCormick, P.J.; Lin, H.M.; Hosseinian, L.; Fischer, G.W. Low intraoperative tidal volume ventilation with minimal PEEP is associated with increased mortality. Br. J. Anaesth. 2014, 113, 97-108. [CrossRef] [PubMed]

107. Sivan, Y.; Deakers, T.W.; Newth, C.J. Effect of positive end-expiratory pressure on respiratory compliance in children with acute respiratory failure. Pediatr. Pulmonol. 1991, 11, 103-107. [CrossRef]

108. Giffin, F.; Greenough, A. Effect of positive end expiratory pressure and mean airway pressure on respiratory compliance and gas exchange in children with liver disease. Eur. J. Pediatr. 1994, 153, 28-33. [CrossRef] [PubMed]

109. Paulson, T.E.; Spear, R.M.; Silva, P.D.; Peterson, B.M. High-frequency pressure-control ventilation with high positive end-expiratory pressure in children with acute respiratory distress syndrome. J. Pediatr. 1996, 129, 566-573. [CrossRef]

110. Tusman, G.; Böhm, S.H.; Tempra, A.; Melkun, F.; García, E.; Turchetto, E.; Mulder, P.G.; Lachmann, B. Effects of recruitment maneuver on atelectasis in anesthetized children. Anesthesiology 2003, 98, 14-22. [CrossRef]

111. von Ungern-Sternberg, B.S.; Regli, A.; Schibler, A.; Hammer, J.; Frei, F.J.; Erb, T.O. The impact of positive end-expiratory pressure on functional residual capacity and ventilation homogeneity impairment in anesthetized children exposed to high levels of inspired oxygen. Anesth. Analg. 2007, 104, 1364-1368. [CrossRef] [PubMed]

112. Khemani, R.G.; Markovitz, B.P.; Curley, M.A.Q. Characteristics of children intubated and mechanically ventilated in 16 PICUs. Chest 2009, 136, 765-771. [CrossRef] [PubMed] 
113. Pulitanò, S.; Mancino, A.; Pietrini, D.; Piastra, M.; De Rosa, S.; Tosi, F.; De Luca, D.; Conti, G. Effects of positive end expiratory pressure (PEEP) on intracranial and cerebral perfusion pressure in pediatric neurosurgical patients. J. Neurosurg. Anesth. 2013, 25, 330-334. [CrossRef] [PubMed]

114. Ingaramo, O.A.; Ngo, T.; Khemani, R.G.; Newth, C.J. Impact of positive end-expiratory pressure on cardiac index measured by ultrasound cardiac output monitor*. Pediatr. Crit. Care Med. 2014, 15, 15-20. [CrossRef] [PubMed]

115. de Jager, P.; Burgerhof, J.G.; van Heerde, M.; Albers, M.J.; Markhorst, D.G.; Kneyber, M.C. Tidal volume and mortality in mechanically ventilated children: A systematic review and meta-analysis of observational studies*. Crit. Care Med. 2014, 42, 2461-2472. [CrossRef] [PubMed]

116. Randolph, A.G. Management of acute lung injury and acute respiratory distress syndrome in children. Crit. Care Med. 2009, 37, 2448-2454. [CrossRef]

117. Cheifetz, I.M. Management of acute lung injury: Sharing data between adults and children. Respir. Care 2011, 56, 1258-1268. [CrossRef]

118. Kneyber, M.C. Intraoperative mechanical ventilation for the pediatric patient. Best Pract. Res. Clin. Anaesthesiol 2015, 29, 371-379. [CrossRef]

119. Fernandez-Bustamante, A.; Wood, C.L.; Tran, Z.V.; Moine, P. Intraoperative ventilation: Incidence and risk factors for receiving large tidal volumes during general anesthesia. BMC Anesth. 2011, 11, 22. [CrossRef]

120. Jaber, S.; Coisel, Y.; Chanques, G.; Futier, E.; Constantin, J.M.; Michelet, P.; Beaussier, M.; Lefrant, J.Y.; Allaouchiche, B.; Capdevila, X.; et al. A multicentre observational study of intra-operative ventilatory management during general anaesthesia: Tidal volumes and relation to body weight. Anaesthesia 2012, 67, 999-1008. [CrossRef]

121. Lellouche, F.; Dionne, S.; Simard, S.; Bussières, J.; Dagenais, F. High tidal volumes in mechanically ventilated patients increase organ dysfunction after cardiac surgery. Anesthesiology 2012, 116, 1072-1082. [CrossRef] [PubMed]

122. Neto, A.S.; Hemmes, S.N.; Barbas, C.S.; Beiderlinden, M.; Fernandez-Bustamante, A.; Futier, E.; Gajic, O.; El-Tahan, M.R.; Ghamdi, A.A.; Günay, E.; et al. Association between driving pressure and development of postoperative pulmonary complications in patients undergoing mechanical ventilation for general anaesthesia: A meta-analysis of individual patient data. Lancet Respir. Med. 2016, 4, 272-280. [CrossRef]

123. Güldner, A.; Kiss, T.; Serpa Neto, A.; Hemmes, S.N.; Canet, J.; Spieth, P.M.; Rocco, P.R.; Schultz, M.J.; Pelosi, P.; Gama de Abreu, M. Intraoperative protective mechanical ventilation for prevention of postoperative pulmonary complications: A comprehensive review of the role of tidal volume, positive end-expiratory pressure, and lung recruitment maneuvers. Anesthesiology 2015, 123, 692-713. [CrossRef]

124. Helmerhorst, H.J.; Roos-Blom, M.J.; van Westerloo, D.J.; de Jonge, E. Association Between Arterial Hyperoxia and Outcome in Subsets of Critical Illness: A Systematic Review, Meta-Analysis, and Meta-Regression of Cohort Studies. Crit. Care Med. 2015, 43, 1508-1519. [CrossRef]

125. Damiani, E.; Adrario, E.; Girardis, M.; Romano, R.; Pelaia, P.; Singer, M.; Donati, A. Arterial hyperoxia and mortality in critically ill patients: A systematic review and meta-analysis. Crit. Care 2014, 18, 711. [CrossRef]

126. Rachmale, S.; Li, G.; Wilson, G.; Malinchoc, M.; Gajic, O. Practice of excessive F(IO(2)) and effect on pulmonary outcomes in mechanically ventilated patients with acute lung injury. Respir. Care 2012, 57, 1887-1893. [CrossRef] [PubMed]

127. Kaplan, E.; Bar-Yishay, E.; Prais, D.; Klinger, G.; Mei-Zahav, M.; Mussaffi, H.; Steuer, G.; Hananya, S.; Matyashuk, Y.; Gabarra, N.; et al. Encouraging pulmonary outcome for surviving, neurologically intact, extremely premature infants in the postsurfactant era. Chest 2012, 142, 725-733. [CrossRef] [PubMed]

128. Jobe, A.H.; Bancalari, E. Bronchopulmonary dysplasia. Am. J. Respir. Crit. Care Med. 2001, 163, $1723-1729$. [CrossRef]

129. Rowland, R.; Newman, C.G. Pulmonary complications of oxygen therapy. J. Clin. Pathol. 1969, 22, $192-198$. [CrossRef]

130. Cohen, M.M.; Cameron, C.B.; Duncan, P.G. Pediatric anesthesia morbidity and mortality in the perioperative period. Anesth. Analg. 1990, 70,160-167. [CrossRef]

131. Gollin, G.; Bell, C.; Dubose, R.; Touloukian, R.J.; Seashore, J.H.; Hughes, C.W.; Oh, T.H.; Fleming, J.; $\mathrm{O}^{\prime}$ Connor, T. Predictors of postoperative respiratory complications in premature infants after inguinal herniorrhaphy. J. Pediatric Surg. 1993, 28, 244-247. [CrossRef] 
132. Steward, D.J. Preterm infants are more prone to complications following minor surgery than are term infants. Anesthesiology 1982, 56, 304-306. [CrossRef] [PubMed]

133. Gregory, G. Life-threatening perioperative apnea in the ex- "premie". Anesthesiology 1986, 65, 651-661. [CrossRef] [PubMed]

134. Kurth, C.D.; Spitzer, A.R.; Broennle, A.M.; Downes, J.J. Postoperative apnea in preterm infants. Anesthesiology 1987, 66, 483-488. [CrossRef]

135. Tiret, L.; Nivoche, Y.; Hatton, F.; Desmonts, J.M.; Vourc'h, G. Complications related to anaesthesia in infants and children. A prospective survey of 40240 anaesthetics. Br. J. Anaesth. 1988, 61, 263-269. [CrossRef]

136. Aplin, S.; Baines, D.; De Lima, J. Use of the ASA Physical Status Grading System in pediatric practice. Paediatr. Anaesth. 2007, 17, 216-222. [CrossRef]

137. Abouleish, A.E.; Leib, M.L.; Cohen, N.H. ASA Provides Examples to Each ASA Physical Status Class. ASA Newsl. 2015, 79, 38-49.

138. Hurwitz, E.E.; Simon, M.; Vinta, S.R.; Zehm, C.F.; Shabot, S.M.; Minhajuddin, A.; Abouleish, A.E. Adding Examples to the ASA-Physical Status Classification Improves Correct Assignment to Patients. Anesthesiology 2017, 126, 614-622. [CrossRef]

139. Jimenez, N.; Posner, K.L.; Cheney, F.W.; Caplan, R.A.; Lee, L.A.; Domino, K.B. An update on pediatric anesthesia liability: A closed claims analysis. Anesth. Analg. 2007, 104, 147-153. [CrossRef]

140. Della Torre, V.; Badenes, R.; Corradi, F.; Racca, F.; Lavinio, A.; Matta, B.; Bilotta, F.; Robba, C. Acute respiratory distress syndrome in traumatic brain injury: How do we manage it? J. Thorac. Dis. 2017, 9, 5368-5381. [CrossRef]

141. Young, N.; Rhodes, J.K.; Mascia, L.; Andrews, P.J. Ventilatory strategies for patients with acute brain injury. Curr. Opin. Crit. Care 2010, 16, 45-52. [CrossRef]

142. Shweikeh, F.; Foulad, D.; Nuño, M.; Drazin, D.; Adamo, M.A. Differences in surgical outcomes for patients with craniosynostosis in the US: Impact of socioeconomic variables and race. J. Neurosurg. Pediatrics 2016, 17, 27-33. [CrossRef]

143. Patria, M.F.; Ghislanzoni, S.; Macchini, F.; Lelii, M.; Mori, A.; Leva, E.; Principi, N.; Esposito, S. Respiratory Morbidity in Children with Repaired Congenital Esophageal Atresia with or without Tracheoesophageal Fistula. Int. J. Environ. Res. Public Health 2017, 14, 1136. [CrossRef] [PubMed]

144. Friedmacher, F.; Kroneis, B.; Huber-Zeyringer, A.; Schober, P.; Till, H.; Sauer, H.; Höllwarth, M.E. Postoperative Complications and Functional Outcome after Esophageal Atresia Repair: Results from Longitudinal Single-Center Follow-Up. J. Gastrointest Surg. 2017, 21, 927-935. [CrossRef] [PubMed]

145. Chandrasekharan, P.K.; Rawat, M.; Madappa, R.; Rothstein, D.H.; Lakshminrusimha, S. Congenital Diaphragmatic hernia-a review. Matern. Health Neonatol. Perinatol. 2017, 3, 6. [CrossRef] [PubMed]

146. Corey, K.M.; Hornik, C.P.; Laughon, M.M.; McHutchison, K.; Clark, R.H.; Smith, P.B. Frequency of anomalies and hospital outcomes in infants with gastroschisis and omphalocele. Early Hum. Dev. 2014, 90, 421-424. [CrossRef]

147. Islam, S. Advances in surgery for abdominal wall defects: Gastroschisis and omphalocele. Clin. Perinatol. 2012, 39, 375-386. [CrossRef]

148. Bakhsheshian, J.; Jin, D.L.; Chang, K.E.; Strickland, B.A.; Donoho, D.A.; Cen, S.; Mack, W.J.; Attenello, F.; Christian, E.A.; Zada, G. Risk factors associated with the surgical management of craniopharyngiomas in pediatric patients: Analysis of 1961 patients from a national registry database. Neurosurg. Focus 2016, 41, E8. [CrossRef]

149. Aleksic, V.; Radulovic, D.; Milakovic, B.; Nagulic, M.; Vucovic, D.; Antunovic, V.; Djordjevic, M. A retrospective analysis of anesthesiologic complications in pediatric neurosurgery. Paediatr. Anaesth. 2009, 19, 879-886. [CrossRef]

150. Wu, L.; Zhang, X.N.; Wang, Y.S.; Liu, Y.Z.; Hai, Y. Risk factors for pulmonary complications after posterior spinal instrumentation and fusion in the treatment of congenital scoliosis: A case-control study. BMC Musculoskelet Disord 2019, 20, 331. [CrossRef]

151. Raval, M.V.; Dillon, P.W.; Bruny, J.L.; Ko, C.Y.; Hall, B.L.; Moss, R.L.; Oldham, K.T.; Richards, K.E.; Vinocur, C.D.; Ziegler, M.M. American College of Surgeons National Surgical Quality Improvement Program Pediatric: A phase 1 report. J. Am. Coll Surg. 2011, 212, 1-11. [CrossRef] [PubMed] 
152. Nafiu, O.O.; Burke, C.C.; Chimbira, W.T.; Ackwerh, R.; Reynolds, P.I.; Malviya, S. Prevalence of habitual snoring in children and occurrence of peri-operative adverse events. Eur. J. Anaesthesiol 2011, 28, 340-345. [CrossRef] [PubMed]

153. von Ungern-Sternberg, B.S.; Habre, W.; Erb, T.O.; Heaney, M. Salbutamol premedication in children with a recent respiratory tract infection. Paediatr. Anaesth. 2009, 19, 1064-1069. [CrossRef] [PubMed]

154. Scalfaro, P.; Sly, P.D.; Sims, C.; Habre, W. Salbutamol prevents the increase of respiratory resistance caused by tracheal intubation during sevoflurane anesthesia in asthmatic children. Anesth. Analg. 2001, 93, 898-902. [CrossRef]

155. von Ungern-Sternberg, B.S.; Sommerfield, D.; Slevin, L.; Drake-Brockman, T.F.E.; Zhang, G.; Hall, G.L. Effect of Albuterol Premedication vs Placebo on the Occurrence of Respiratory Adverse Events in Children Undergoing Tonsillectomies: The REACT Randomized Clinical Trial. JAMA Pediatr. 2019, 173, 527-533. [CrossRef]

156. Patino, M.; Sadhasivam, S.; Mahmoud, M. Obstructive sleep apnoea in children: Perioperative considerations. Br. J. Anaesth. 2013, 111 (Suppl. 1), i83-i95. [CrossRef]

157. Valley, R.D.; Freid, E.B.; Bailey, A.G.; Kopp, V.J.; Georges, L.S.; Fletcher, J.; Keifer, A. Tracheal extubation of deeply anesthetized pediatric patients: A comparison of desflurane and sevoflurane. Anesth. Analg. 2003, 96, 1320-1324. [CrossRef]

158. Patel, R.I.; Hannallah, R.S.; Norden, J.; Casey, W.F.; Verghese, S.T. Emergence airway complications in children: A comparison of tracheal extubation in awake and deeply anesthetized patients. Anesth. Analg. 1991, 73, 266-270. [CrossRef]

159. Šešlija, N.; Janković, I.; Rosić, R.; Milenković, A. The importance of preoperative assessment and children preparation in determination and reduction of anesthetic risks. Anesth. Iugosl. 1996, 21, 155-160.

160. Dimick, J.B.; Chen, S.L.; Taheri, P.A.; Henderson, W.G.; Khuri, S.F.; Campbell, D.A.,Jr. Hospital costs associated with surgical complications: A report from the private-sector National Surgical Quality Improvement Program. J. Am. Coll Surg. 2004, 199, 531-537. [CrossRef]

161. Johnson, R.G.; Arozullah, A.M.; Neumayer, L.; Henderson, W.G.; Hosokawa, P.; Khuri, S.F. Multivariable predictors of postoperative respiratory failure after general and vascular surgery: Results from the patient safety in surgery study. J. Am. Coll Surg. 2007, 204, 1188-1198. [CrossRef] [PubMed]

162. Oofuvong, M.; Ratprasert, S.; Chanchayanon, T. Risk prediction tool for use and predictors of duration of postoperative oxygen therapy in children undergoing non-cardiac surgery: A case-control study. BMC Anesth. 2018, 18, 137. [CrossRef]

163. Gupta, H.; Gupta, P.K.; Fang, X.; Miller, W.J.; Cemaj, S.; Forse, R.A.; Morrow, L.E. Development and validation of a risk calculator predicting postoperative respiratory failure. Chest 2011, 140, 1207-1215. [CrossRef]

164. Brueckmann, B.; Villa-Uribe, J.L.; Bateman, B.T.; Grosse-Sundrup, M.; Hess, D.R.; Schlett, C.L.; Eikermann, M. Development and validation of a score for prediction of postoperative respiratory complications. Anesthesiology 2013, 118, 1276-1285. [CrossRef]

165. Ramachandran, S.K.; Haider, N.; Saran, K.A.; Mathis, M.; Kim, J.; Morris, M.; O’Reilly, M. Life-threatening critical respiratory events: A retrospective study of postoperative patients found unresponsive during analgesic therapy. J. Clin. Anesth 2011, 23, 207-213. [CrossRef]

166. Taylor, S.; Kirton, O.C.; Staff, I.; Kozol, R.A. Postoperative day one: A high risk period for respiratory events. Am. J. Surg. 2005, 190, 752-756. [CrossRef] [PubMed]

167. Verghese, S.T.; Hannallah, R.S. Acute pain management in children. J. Pain. Res. 2010, 3, 105-123. [CrossRef] [PubMed]

168. Chertin, B.; Zeldin, A.; Kocherov, S.; Ioscovich, A.; Ostrovsky, I.A.; Gozal, Y. Use of Caudal Analgesia Supplemented with Low Dose of Morphine in Children Who Undergo Renal Surgery. Curr. Urol. 2016, 9 , 132-137. [CrossRef]

169. van Lier, F.; van der Geest, P.J.; Hoeks, S.E.; van Gestel, Y.R.; Hol, J.W.; Sin, D.D.; Stolker, R.J.; Poldermans, D. Epidural analgesia is associated with improved health outcomes of surgical patients with chronic obstructive pulmonary disease. Anesthesiology 2011, 115, 315-321. [CrossRef]

170. Chidambaran, V.; Tewari, A.; Mahmoud, M. Anesthetic and pharmacologic considerations in perioperative care of obese children. J. Clin. Anesth. 2018, 45, 39-50. [CrossRef] 
171. Mahmoud, M.; Mason, K.P. Dexmedetomidine: Review, update, and future considerations of paediatric perioperative and periprocedural applications and limitations. Br. J. Anaesth. 2015, 115, 171-182. [CrossRef] [PubMed]

172. Hodgson, L.E.; Murphy, P.B.; Hart, N. Respiratory management of the obese patient undergoing surgery. J. Thorac. Dis. 2015, 7, 943-952. [CrossRef]

173. Branson, R.D. The scientific basis for postoperative respiratory care. Respir. Care 2013, 58, $1974-1984$. [CrossRef]

174. Cuello-Garcia, C.A.; Mai, S.H.C.; Simpson, R.; Al-Harbi, S.; Choong, K. Early Mobilization in Critically Ill Children: A Systematic Review. J. Pediatr. 2018, 203, 25-33.e26. [CrossRef]

175. Choong, K.; Awladthani, S.; Khawaji, A.; Clark, H.; Borhan, A.; Cheng, J.; Laskey, S.; Neu, C.; Sarti, A.; Thabane, L.; et al. Early Exercise in Critically Ill Youth and Children, a Preliminary Evaluation: The wEECYCLE Pilot Trial. Pediatr. Crit. Care Med. 2017, 18, e546-e554. [CrossRef] [PubMed]

176. Cassidy, M.R.; Rosenkranz, P.; McCabe, K.; Rosen, J.E.; McAneny, D. I COUGH: Reducing postoperative pulmonary complications with a multidisciplinary patient care program. JAMA Surg. 2013, 148, 740-745. [CrossRef] [PubMed]

(C) 2020 by the authors. Licensee MDPI, Basel, Switzerland. This article is an open access article distributed under the terms and conditions of the Creative Commons Attribution (CC BY) license (http://creativecommons.org/licenses/by/4.0/). 